\title{
The Determinants of Subjective Well-Being in a Developing Country: The Ecuadorian Case
}

\author{
Nicola Pontarollo ${ }^{1,2}$ (D) Mercy Orellana ${ }^{3}$ (D) Joselin Segovia ${ }^{3}$ (D) \\ Published online: 31 December 2019 \\ (c) The Author(s) 2019
}

\begin{abstract}
In this study, we identify some individual and contextual factors potentially affecting subjective well-being in developing countries and check their effect in the Ecuadorian case. Ecuador is an oil country where attempts have been made to overcome deep social and territorial inequalities by placing human well-being at the core of public policy through the National Plan for Good Living. By means of ordinary least squares and ordered logit with clustered standard errors, as well as multilevel ordered logit models, we find that oil-dependent territories negatively affect well-being. Moreover, women and indigenous people report lower well-being, while personal income, education, housing quality, institutional trust, health insurance and social relationships can improve it. From a policy perspective, we find that basic unmet needs still need to be fulfilled to increase well-being, and further improvements of the institutional framework, redistributive system and inclusion policies are required. In this respect, we observe that Good Living-based policy accurately addresses these elements and, therefore, has great potential for application in other countries with similar characteristics.
\end{abstract}

Keywords Individual well-being $\cdot$ Ecuador $\cdot$ Individual characteristics · Contextual factors · Multilevel model

\begin{abstract}
Nicola Pontarollo: The scientific output expressed does not imply a policy position of the European Commission. Neither the European Commission nor any person acting on behalf of the Commission is responsible for the use which might be made of this publication. The authors thank the Co-editors Stephanie Rossouw and Talita Dalton-Greyling for the helpful comments that significantly improved the paper. Further, thanks are extended to Diego Ontaneda for the helpful support with the graphical parts.
\end{abstract}

Nicola Pontarollo

nicola.pontarollo@unibs.it

Mercy Orellana

mercy.orellana@ucuenca.edu.ec

Joselin Segovia

joselin.segovias@ucuenca.edu.ec

1 European Commission, Joint Research Centre (JRC), Ispra, Italy

2 Department of Economics and Management, University of Brescia, Brescia, Italy

3 GIER, Universidad de Cuenca, Cuenca, Ecuador 
JEL Classification $\mathrm{I} 30 \cdot \mathrm{P} 16 \cdot \mathrm{C} 30$

\section{Introduction}

In recent years, subjective well-being has provoked increasing interest from both social science researchers and governmental institutions. In developed countries, it is worth mentioning the Canadian Index of Wellbeing, the measure of "equitable and sustainable wellbeing" in the Italian State Balance in 2016, as well as policy initiatives related to wellbeing in the UK (Dolan et al. 2011), France (Tavernier et al. 2015) and Germany (Die Bundesregierumg 2017). Developing countries are also beginning to consider well-being formally, with Mexico, Brazil and Ecuador including it in their constitutions. In the latter, well-being is incorporated through the principle of "good living", based on sumak kawsay, an ancestral Quechua concept focused on a holistic approach to human well-being, involving harmony with oneself, the community and nature (see Caria and Domínguez 2016, for further details).

In light of the originality of the Ecuadorian case, this paper aims to identify and analyze the individual and contextual dimensions of subjective well-being in this country, which is an interesting case study for at least three reasons: First, it is one of the few cases worldwide in which well-being is explicitly included in the constitution as a national goal. Second, like other countries in the region, it experienced rapid economic growth due to the commodities supercycle in the past decade, which increased the government's revenues and allowed the implementation of a variety of strategies to improve well-being. Third, it allows us to draw some conclusions of general interest for other developing countries, especially in Latin America.

To our knowledge, only Ramirez (2009) has conducted a study to estimate the determinants of life satisfaction in Ecuador. The author includes a set of subjective and objective variables at the individual level and finds that the effect of the former outweighs the effect of objective variables on life satisfaction. Among objective variables, leisure hours and income increase life satisfaction, while being indigenous or being male translates into lower reported well-being. The subjective variables with the highest impact over life satisfaction are social relationships and civil status. Despite the importance of this contribution, we identify some unsolved aspects. First, the inclusion of mostly subjective variables may have led to endogeneity problems that are not discussed (Kuroki 2011). In addition, the study does not explicitly account for (1) variables linked to the National Plan for Good Living and (2) contextual effects, to account for the significant territorial inequalities in Ecuador (Mendieta Muñoz and Pontarollo 2016).

To overcome these limitations, in our analysis, we mostly use objective variables and add to the general literature on subjective well-being by identifying a set of individual and contextual variables specific to our case study that are linked to the goals of the National Plan for Good Living. These variables include institutional trust, health insurance, indigenous ethnicity and housing quality at the individual level and oil dependency, urbanization and natural hazards at the contextual level.

Regarding the empirical technique, we adopt an OLS and ordered logit approach with clustered standard errors, and an ordered logistic multilevel analysis to account for the nested structure of the data, i.e., individual observations within distinct territorial units. This provides methodological strength to our results and allows us to check the robustness of our estimates. 


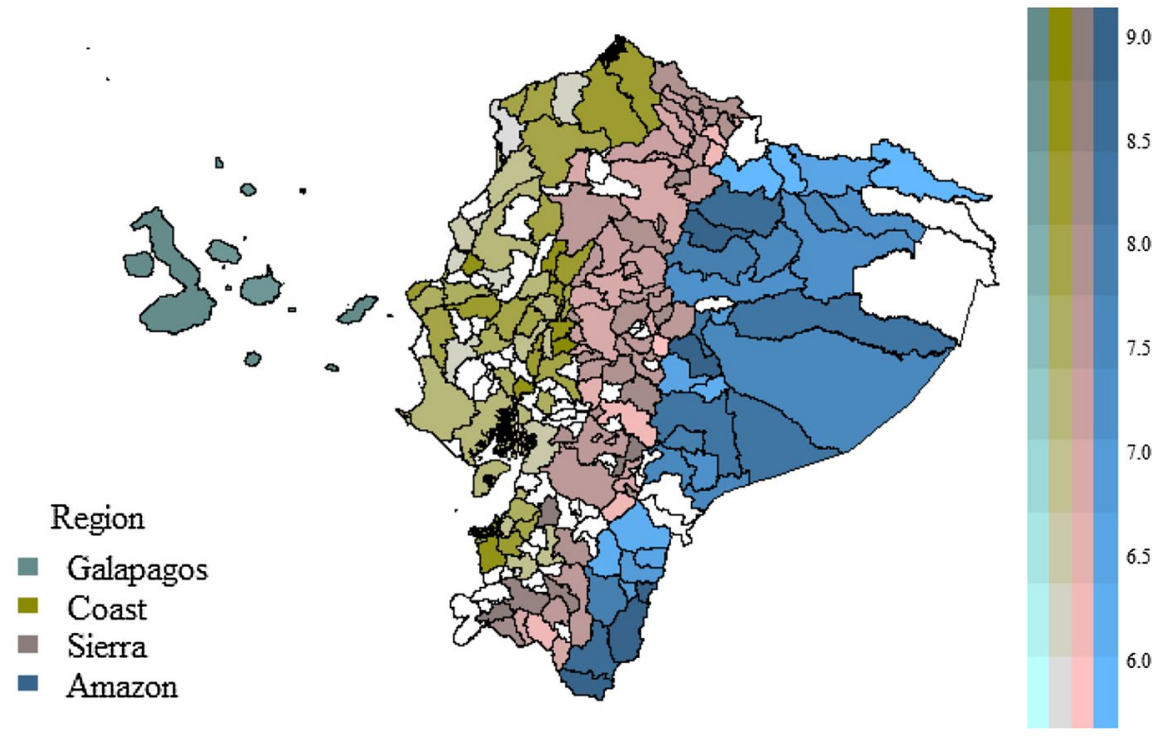

Fig. 1 Well-being across cantons in Ecuador in 2015. Source: Authors' elaboration based on ENEMDU, INEC 2015

This paper is organized as follows. Section 2 describes the background and the dimensions of well-being in the Latin American context and in Ecuador in particular. Section 3 explains the methodology and the data. In Sect. 4, we present and discuss the results of the empirical analysis, and in the last section, we draw some conclusions and policy implications.

\section{Background and Well-Being Dimensions}

\subsection{The Ecuadorian Context}

Ecuador is a country with an estimated population of 16.5 million. It is divided into four geographic regions (the Andes, Amazonia, the Coast and the Galapagos), 24 provinces, 221 cantons and 1228 parishes (Fig. 1). Each of its four regions has its own climate and biodiversity conditions. Ecuador is a rich country in terms of natural resources, although it is also highly exposed to natural disasters (Demoraes and D'Ercole 2001). According to the World Bank (2015), 36\% of Ecuador's population lives in rural areas, one of the highest rates in South American countries. The last census information shows that the ten most populated cities account for half of the population of the country, and the two main cities, Quito and Guayaquil, account for one-third and a half of the gross value added (GVA), respectively (Central Bank of Ecuador 2017).

The Ecuadorian population has historically been subject to poverty and social inequality (SENPLADES and SETEP 2014). Poverty has particularly affected women, indigenous 
groups $^{1}$ and rural populations (BTI 2016). The national economy relies mainly on oil exports as well as on other commodities, which has constantly exposed the country to price volatility and, therefore, to periodic sharp economic downturns.

Limited access to basic services, housing, education and healthcare is strongly present in the central Andes, north Amazonia and rural areas, particularly affecting indigenous households (SENPLADES 2009, 2013a, b). As a result, spatial heterogeneity and profound social and economic territorial disparities persist (Mendieta Muñoz and Pontarollo 2016).

In 2007, left-wing president Rafael Correa took office and promoted the drafting of a new constitution based on "good living", or sumak kawsay, which was adopted in 2008. This resulted in major improvements in access to basic services, the rights of women and ethnic minorities and, moreover, to an acknowledgement of the rights of nature (Freedom House 2017). With this constitutional change, human well-being, through the good living concept, was adopted as a policy objective in public planning. To this extent, the national government designed, in 2008, its main strategic plan, the National Plan for Good Living (SENPLADES 2013a, b). Here, the concept of good living is defined as:

"covering needs, achieving a dignified quality of life and death; loving and being loved; the healthy flourishing of all individuals in peace and harmony with nature; and achieving an indefinite reproduction of human cultures. Good Living implies having free time for contemplation and personal emancipation; enabling the expansion and flourishing of people's liberties, opportunities, capabilities and potentialities to simultaneously allow society, specific territories, different collective identities, and each individual, understood both in universal and relative terms, to achieve their objectives in life (without causing any kind of material or subjective dominance over any other individual). Our concept of Good Living compels us to re-build the public sphere in order to recognize, understand and value ourselves as diverse but equal individuals, and in order to advance reciprocity and mutual recognition, enable selfadvancement, and build a shared social future".

The plan is operationalized through twelve overarching objectives intended to address national needs and to foster social and economic justice. The objectives aim (1) to consolidate democratic governance and build people's power, (2) to foster social and territorial equity, cohesion and inclusion, (3) to improve people's quality of life, (4) to strengthen citizen's capacities and potential, (5) to build spaces for social interaction and strengthen national identity, diverse identities, pluri-nationality and interculturality, (6) to consolidate the transformation of the judicial system and reinforce comprehensive security, with strict respect for human rights, (7) to guarantee the rights of nature and promote global environmental sustainability, (8) to consolidate the solidarity of the social and economic system, (9) to guarantee dignified work in all forms, (10) to promote transformation of the productive structure, (11) to ensure the sovereignty and efficiency of the strategic sectors for industrial and technological transformation, (12) to guarantee sovereignty and peace, enhancing strategic insertion worldwide and Latin American integration (SENPLADES 2013b, pp. 47-50).

In the last decade, important goals within the National Plan for Good Living were achieved thanks to the revenues from high oil prices. This allowed public expenditure to double, especially through major infrastructure investment and increasing public sector wages and subsidies (BTI 2016). Among the main objectives achieved, inequality and unemployment rates were significantly reduced, and poverty and extreme poverty rates fell

${ }^{1}$ According to the last census, indigenous people represent $7 \%$ of the population. 
by $38 \%$ and $47 \%$, respectively (BTI 2016). Educational enrolment rates increased at various levels thanks to government expenditure. The largest increase was in higher education, which rose from $0.7 \%$ of GDP in 2006 to $2.1 \%$ in 2016, the highest rate in Latin America (CEPR 2017). Furthermore, one of the greatest achievements during the last decade was the increase of the minimum wage by $48 \%$ in real terms, which allowed the reference household income to exceed the cost of the basic consumer basket for the first time in 2014 (IMF 2015).

Despite the social progress attained, many challenges remain. According to the National Institute of Statistics and Census (INEC), 61\% of indigenous people in Ecuador report unsatisfied basic needs, and only $54 \%$ of households report good housing conditions with respect to wall quality (INEC 2015). Furthermore, the public administration has been criticized regarding the rights and freedoms of the population: In the past years, indigenous movements and labor unions have been weakened, and there is permanent conflict between the government and the media (BTI 2016). From an economic perspective, the greatest challenges faced by the country are its low level of foreign direct investment and its oil dependency (BTI 2016). Since 2013, given the decline of oil prices, the public administration has been forced to cut the public budget (in 2015), and the share of social spending as a proportion of GDP reached its lowest value since 2010 (CEPR 2017).

\subsection{Well-Being Dimensions}

In this study, individual and contextual dimensions of well-being are considered. Both include a set of variables taken from the general literature on the determinants of wellbeing and another set related to the socio-economic and socio-demographic context of Latin America, and specifically of Ecuador.

\subsubsection{Individual Dimensions}

Apart from the standard individual dimensions that affect well-being, like age, sex, income and education level, civil status, employment status and socio-economic status (Easterlin 1974; Kuroki 2011; Gómez et al. 2016; Kahneman and Deaton 2010; Shams 2016), we include a set of factors that specifically describe the Latin American context, where high levels of life satisfaction are experienced despite poor performance in several social, institutional and economic indicators (Rojas 2018; Beytía 2016; Morris and Klesner 2010). It has been argued that one of the factors underlying this apparent paradox is the role of social relationships, highlighting that the family is the core unit of close and reciprocal interactions (Neri 2016), which has been proven to have a significant positive link with happiness (Rojas 2018). Collectivist values are the basis of Latin American societies (Hofstede 1984), and Martínez (2007) argues that this is the result of the limited access to labor markets and the state's low capacity to provide welfare services, prompting families and social networks to take a role in producing these services, thus becoming a key element for well-being.

In Ecuador, the importance of family is formally recognized in the good living framework, which states that one of the three main requirements for living well is to be in harmony with the family and the community, which is achieved by developing and keeping good relationships (Caria and Domínguez 2016). In line with this, the Time-Use Survey (Coordinating Minister of Social Development 2014) shows that in Ecuador, spending time with family is the second most common leisure activity by time-use after watching 
$\mathrm{TV}$, with $17 \%$ of leisure time assigned to this activity, compared to $13 \%$ assigned to personal care, $10 \%$ to sports and $7 \%$ to other social activities (Coordinating Minister of Social Development 2014). This pattern holds in other countries in Latin America (INEC 2018; DANE 2018), as well as in Asia and Africa, but differs from OECD countries, where family time is significantly lower and the second most common leisure activity groups hobbies, computer games and arts and crafts (OECD 2009). Therefore, we conjecture that leisure time has different meanings for people in developed and in developing regions. Consequently, we include in our analysis a variable on satisfaction with leisure time, which reasonably proxies time spent with family, expecting a positive relationship with well-being.

Another strategy through which we try to capture social relationships is by including internet access in our analysis. We propose this for two reasons. The first is related to evidence showing that information and communication technology (ICT) has a positive effect on well-being by acting as a new platform to develop and maintain social relationships (Kavetsos and Koutroumpis 2011; Pénard et al. 2013; Ganju et al. 2016; Bargh and McKenna 2004). The second reason relies on the importance of internet and ICT communication to maintain family ties and well-being in countries with high emigration rates (Nedelcu 2012; Dekker and Engbersen 2014; Bacigalupe and Cámara 2012; Benítez 2012). The Ecuadorian case, as shown by Espinosa et al. (2019), is emblematic because since 2000 , emigration has grown rapidly; nowadays, around one-fifth of the population lives abroad but without appropriately integrating with natives, keeping strong ties with the origin country and having strong preferences for family reunification (Leifsen and Tymczuk 2012). Therefore, as well as for leisure time, we expect that internet use, as it approximates social ties, will have a positive impact on well-being.

Other variables of particular interest address specificities of Latin America and of developing countries in general and include the area of residence (urban or rural), institutional trust, ethnicity, the importance attributed to religion, health insurance and housing conditions. The type of area is incorporated in our analysis to explore the effects of living in urban areas compared to rural areas. While this effect could be null (Knight et al. 2009; Valente and Berry 2016) or even negative (Hudson 2006), we would expect it to be positive due to the significantly greater availability of services and opportunities that urbanized areas provide in developing countries such as Ecuador. For instance, our dataset shows that $95 \%$ of urban households have access to the public water supply and $81 \%$ to adequate sanitation, compared to $48 \%$ and $29 \%$ of rural households, respectively (INEC 2015). In addition, the difference in job opportunities means that nine out of ten workers with higher education are settled in urban territories, and about $90 \%$ of hospitals are located in these areas.

Another area of strong interest for well-being in the region is institutional trust. According to data from the World Values Survey (2015), Latin America presents lower rates of institutional trust by approximately one-third to a half with respect to western European countries and the US. Morris and Klesner (2010) show that there is a mutual relationship between a lack of institutional trust and corruption, and according to Rojas (2018), corruption negatively affects well-being. While Ecuador performs poorly in institutional indicators such as the Corruption Perception Index, where it ranks 106 out of 167 (Transparency International 2015), the 2008 constitution introduced various measures aimed at engaging people in the decision-making processes at the local level (see, for example, articles 275, 276, 278 and 279). This might allow for the exploitation of social capital and prevent it from remaining enclosed in small groups with similar socio-economic characteristics (Mendoza-Botelho 2013), with potentially positive effects on well-being. Consequently, we argue that institutional trust, since it might be linked to the perception of more harmonious and inclusive local development processes, might increase well-being. 
Another important aspect of Latin America is the presence of large and often less wealthy communities of indigenous people, which account for nearly 8 percent of the total population, representing one the largest ethnic minority groups in many countries (World Bank 2015). Ecuador is the fourth country in the region in terms of the presence of indigenous people, who make up 7 percent of the population, around 1 million in absolute terms. This minority has historically been affected by social, economic and political exclusion, and therefore, by a lower quality of life (Massala and Moni 2019), which has led to the introduction of several measures aimed at enforcing ethnic minority rights and integrating these groups into the labor market. ${ }^{2}$ This has resulted in great achievements such as significant poverty alleviation, increased education and broader access to basic services for indigenous people, for which Ecuador has been praised (World Bank 2015). In spite of this and the favorable institutional framework, opportunities are far from being equal among ethnicities, and Canelas and Salazar (2014), for example, show that the ethnic wage gap is still quite strong in the country. These opposite perspectives lead us to not have an a priori expectation on the sign of the variable accounting for the effect of ethnicity on well-being.

Another characteristic of Latin America is the relevance attributed to religion. Latin America represents the third most religious region after Africa and the Middle East (Gallup International 2017), and in Ecuador, 91.95\% of the population reports having a religious belief (INEC 2012). Helliwell and Putnam (2004) and Rodríguez-Pose and von Berlepsch (2014) show that both religiosity and religious activity are positive drivers of well-being. It is expected that, in line with this, well-being increases with religiosity in Ecuador.

Health insurance is inherently important to human well-being, and it can make a difference in a region characterized by wealth inequalities such as Latin America, where coverage is not universal (Dmytraczenko and Almeida 2015). This creates critical differences from more developed regions, such as high unmet health needs and impoverishment risk. Dmytraczenko and Almeida (2015) show that around 2 to 4 million people in the region have been driven into poverty due to out-of-pocket health spending. To tackle this, governments have implemented policies and programs to expand health coverage, leading some countries to attain outcomes comparable to those of the developed world, significantly improving well-being (Dmytraczenko and Almeida 2015). However, this has not been the case in Ecuador, where more than half of the population still lacks access to health insurance (INEC 2015). We draw on this evidence to include health insurance information in our analysis, expecting it to be a positive driver of well-being.

In Latin America, finally, housing provision is a concern that stems beyond the quantity of required infrastructure since quality ${ }^{3}$ has long been an unattended social issue (Comes et al. 2018). Data from the Inter-American Development Bank shows that the quantitative deficit represents only $6 \%$ of the total housing deficit in urban areas in the region, while the qualitative deficit represents $94 \%$ (Comes et al. 2018). Housing conditions can trigger or block people's capacity and liberty to achieve well-being; therefore, they represent another important indicator of well-being. Lora (2008) gives credit to this link, showing that housing and safety satisfaction are key drivers of life satisfaction. Accordingly, the effect of

\footnotetext{
2 The main innovations (Title 2, Chapter 4 of the Constitution) have to do with the inclusion of new collective rights, such as the right not to be the object of racism or discrimination, to maintain their own legal systems and organizations, and to be consulted before the adoption of legislative measures that may affect these peoples or groups.

${ }^{3}$ Housing quality refers to house tenure, construction materials, safety, access to basic services, and more recently, access to public spaces, transportation and education (Comes et al. 2018).
} 
housing conditions on well-being, by including safety information and tenure, is expected to be positive.

\subsubsection{Contextual Dimensions}

To take into account the territorial heterogeneity present in Latin America (Modrego and Berdegué 2015) and its salience in Ecuador (Mendieta Muñoz and Pontarollo 2016; Orellana Bravo et al. 2016), we incorporate a set of contextual dimensions to check whether and how they affect well-being, with particular attention paid to the (1) general dimensions addressed by the literature and (2) context-specific dimensions of developing countries, and of Ecuador in particular. In the first group, the percentage of urban area, gross value added and an income inequality index (Gini) are included. The second group includes a natural hazards index (Demoraes and D'ercole 2001) and a dummy related to the presence of oil mining activity. The cantonal variable indicating the percentage of people living in urban areas accounts for the quantity of services and job sources, as well as possible congestion costs. According to the relevance of the positive and negative factors, living in an urban area may have a positive, negative or neutral impact on life satisfaction. ${ }^{4}$

Gross value added (GVA) is included in our analysis as a proxy of GDP, to associate the average cantonal level of production to well-being. This dimension has been the focus of several economic policies implemented in Ecuador with the objective of increasing the value added in production as well as to improve quality of life (SENPLADES 2013b). According to Stiglitz et al. (2009), well-being is closely related to income and, therefore, consumption. Measures of production, like GVA, however, do not inherently translate into individual income. Assuming the opposite would result in the inaccurate assumption of a positive relationship between production measures and individual well-being. Like the related literature (Deeming and Jones 2015; Rozer and Kraaykamp 2013; Zagorski et al. 2014), we hypothesize that production increases contextual income and this, in turn, increases individual well-being.

Income inequality represents another important characteristic to study in well-being research (Alesina et al. 2004). Nevertheless, results with respect to this factor are inconclusive (Graham and Felton 2006) as it can have a positive, negative or no statistically significant effect, depending on the aggregated income level (Rozer and Kraaykamp 2013). Theoretically, inequality has a high social cost due to its limiting effect on democracy and development, which negatively affects growth and efficiency (Stiglitz 2014). According to the Lora (2008), high poverty rates in Latin America are the result of high levels of inequality in the distribution of income. Furthermore, Ecuador has reported high inequality rates throughout its history, which supports the insertion of this variable in our study. We would expect, then, that it is negatively associated with well-being.

The simultaneous inclusion of average GVA and inequality is furthermore important because "there is also specific evidence that the omission of per capita GDP can seriously distort the effect of inequality" Zagorski et al. (2014, p. 1095). Ecuador's development model has traditionally been linked to the oil extraction sector. Seven out of 157 cantons rely on the oil extraction industry, four of which are located in the Amazon region and three in the Coast region. While on the one hand, it can positively affect well-being through the public revenue it generates, as reported by Gadom (2017), on the other hand, it can also have a negative effect

\footnotetext{
4 This variable is different from the individual variable indicating whether a person lives in an urban area. Indeed, a person can live in an urban area in a canton where the majority of people live in rural areas, or vice versa.
} 
through inequality and environmental degradation (Chiasson-LeBel 2016). Oil exploitation in non-industrialized countries, such as Ecuador, is expected to have a negative effect on subjective well-being because it has an enclave nature and is not considered a high-quality job source. Furthermore, besides the unequal distribution of the resulting oil rents, this industry does not generate spill-over effects to other industries of the economy (Ayelazuno 2014).

Finally, living in a country highly exposed to natural hazards is likely to negatively affect quality of life (Garschagen et al. 2016; Hudson et al. 2019). As Ecuador ranks 58 out of 171 countries in terms of its natural hazards index (Garschagen et al. 2016), we would expect a significant and negative effect of this variable on well-being. In order to explore this, we introduce a natural hazards index built by Demoraes and D'Ercole (2001) into our analysis, based on a set of indicators about seismic and volcanic activity along with tsunami, landslide, flood and drought hazards (see "Appendix 1" for details).

\section{Empirical Strategy}

Our empirical model is based on Fleche et al. (2011) and Blanchflower and Oswald (2004) and adopts the following structure:

$$
\text { Life satisfaction }_{i c}=\alpha+\beta \text { individual }_{i c}+\gamma \text { contextual }_{c}+\varepsilon_{i},
$$

where the subscripts $i$ and $c$ represent individual and local administrative units (cantons), respectively. Individual is a vector of personal variables, while contextual represents a set of territory-specific variables and $\varepsilon_{i}$ is the error term. Following the approach of Alesina et al. (2004), Rodríguez-Pose and von Berlepsch (2014) and Rozer and Kraaykamp (2013), among others, we largely avoid the inclusion of subjective assessment variables because they may be highly endogenous with the dependent variable (Kuroki 2011). The data will be discussed in detail in the next section.

The dependent variable life satisfaction ${ }_{i c}$ is self-reported life satisfaction, which is an ordered categorical variable, while true well-being is a latent variable that is unobservable. This information comes from the National Survey on Employment, Unemployment and Underemployment 2015 (ENEMDU, December edition), provided by the National Institute of Statistics and Census (INEC 2015). ${ }^{5}$ It is defined by a question in which, using a Cantril ladder, respondents are asked to assess their lives (Helliwell et al. 2017) ${ }^{6}$ by replying to the question "If 0 means totally unhappy and 10 totally happy, how do you feel regarding all aspects of your life taken together?" Following Rodríguez-Pose and von Berlepsch (2014), despite the different connotations of the terms life satisfaction, subjective well-being and well-being, we use them interchangeably.

Given the data availability, our paper considers only respondents identified as heads of household. Furthermore, we limited our analysis to cantons where more than 30 individuals were interviewed, resulting in a total database of 157 cantons and 21,265 individuals. A robustness check is conducted in three subsamples by varying the minimum size of cantons to at least 50, 70 and 90 interviewed individuals.

\footnotetext{
5 The ENEMDU dataset comes from a quarterly survey exploring employment, educational attainment, housing services and conditions, consumption and self-perception questions. The surveys of June and December are almost double the sample size of the others and contain questions about self-perception on which we rely to represent life satisfaction.

6 Subjective well-being comprises three dimensions: hedonic, eudaimonic and evaluative (see OECD (2013) for a revision of these concepts). Due to the broad development of the conceptual framework for research on and given data availability, in this study we focus on the evaluative dimension.
} 
Ecuadorians report an average life satisfaction level equal to 7.49. The spatial distribution of well-being is highly heterogeneous, however. Oil cantons, located in the north of the Amazon region (northeast on the map), report the lowest levels of well-being: 7.10; while the Galapagos territories (western islands) report the highest level. Reported life satisfaction is a reporting function of real-life satisfaction. Since the dependent variable in this study is measured on an ordinal scale, the empirical analysis is conducted through the use of an ordered logistic regression (Blanchflower and Oswald 2004; Fleche et al. 2011; Rodríguez-Pose and von Berlepsch 2014). In addition, we adopt an OLS analysis since this is an alternative to ordered logistic regression, where the dependent variable can also be treated as cardinal, at least in practice if not in theory (Van Praag and Ferrer-i-Carbonell 2008). Ferrer-i-Carbonell and Frijters (2004), Graham and Nikolova (2015) and Rodríguez-Pose and von Berlepsch (2014), among others, report that the application of OLS to the estimation of the determinants of subjective well-being has resulted in quite similar outcomes to those obtained using ordered logistic regressions.

As detailed in Sect. 2.2, individual and contextual dimensions of well-being are included as control variables. All covariates at the individual level are taken from ENEMDU 2015. Among these variables, whose descriptive statistics are in "Table 3 in Appendix 2", it is important to note that income is included in deciles in order to elucidate in detail the type of relationship between this individual characteristic and life satisfaction (Blanchflower and Oswald 2004; Rodríguez-Pose and von Berlepsch 2014; Easterlin 1974). In addition, housing conditions are proxied by the condition of walls since the dataset shows that this is highly representative of overall housing conditions: an optimal condition of walls is accompanied by an optimal condition of floors and roofs $82 \%$ of the time.

Contextual variables are defined at the cantonal level and come from several sources. The percentage of urban area and the per capita gross value added are provided by the Central Bank of Ecuador, an income inequality index (Gini) is obtained from the ENEMDU 2015 and the natural hazards index is taken from Demoraes and D'ercole (2001) (see "Appendix 1" for details). A summary of the definitions and descriptive statistics of both types of control variable is provided in "Appendix 2". Correlation matrix is in "Appendix 3".

To deal with the contextual variables discussed above, we also adopt an ordered logistic multilevel approach including random intercepts and fixed slope coefficients (Rozer and Kraaykamp 2013). According to Deeming and Jones (2015), there is a natural congruence between the multilevel random coefficients approach and the aim of incorporating contextspecific determinants to investigate the determinants of individual well-being. By modelling both individuals and their contexts simultaneously, with this analysis we work under the assumption that there is a general pattern that holds across groups of a population belonging to the same canton and that random intercepts are established by each of them to allow for variation that we do not model (Hox 1995). In multilevel analysis, the dependent variable is considered at Level 1, individuals in our case, who are nested in cantons (Level 2). An analogous choice was made by Ballas and Tranmer (2012) because multilevel models, among their other advantages, allow us to explicitly avoid the issue of endogeneity bias (Rice and Jones 1997).

Furthermore, to address the hierarchical structure of the dataset, we estimate clustered standard errors at the cantonal level for OLS and ordered logistic models (Alesina et al. 2004; Graham and Felton 2006; Di Tella et al. 2001). As Moulton (1986) shows, when the nesting of observations within geographical units is not considered, the unobserved characteristics that individuals within this unit share are not accounted for, leading to an underestimation of the standard errors of the dependent variables. This is due to the within-group (intra-class) correlation across individual units. 
Finally, it is worth mentioning that, like much of the well-being literature, we cannot claim unequivocal causal relationships, in particular for variables such as leisure time, institutional trust and employment, as we do not explicitly deal with the issue of endogeneity. Unfortunately, an instrumental variables strategy to tackle this problem is not easy to implement because our data comes from a labor force survey where a portion of the questions is related to subjective measures of life and another to objective measures, and because we cannot follow individuals over time. Therefore, as already mentioned, our strategy to reduce the probability of bias due to endogeneity was i) to avoid subjective variables among the regressors as much as possible and ii) to minimize issues related to omitted variables by including contextual variables and controlling for unobserved heterogeneity across places via a multilevel model.

\section{Results}

The results of Eq. (1) are presented in Table 1. In line with previous research (see, for example, McNeish et al. 2017), the estimations performed through multilevel, OLS and ordered logit models show similar results in terms of standard errors and coefficients. The great majority of results prove to be robust to changes in the minimum size of cantons, as shown in "Appendix 4". Endogenous placement is tested by estimating our model on the subsample of people who never moved from their cantons and on the subsample of people who lived in different places before moving to the canton in which they were interviewed. The likelihood Chow test fails to reject the null hypothesis of coefficient stability between the two groups (at the $1 \%$ significance level). These results, available upon request, support the hypothesis that endogenous placement has no relation to well-being. Personal characteristics commonly included in the literature appear to be largely in line with previous findings. In particular, marriage, education, employment, income and socio-economic status (managerial, scientific or intellectual jobs) display a positive and highly significant effect on individual well-being (Frey and Stutzer 2000; Helliwell 2002; Dugain and Olaberría 2015; Krauss and Graham 2013; Di Tella et al. 2001; Helliwell et al. 2017; Blanchflower and Oswald 2004; Deeming and Jones 2015). It is worth mentioning that the relationship between income and subjective well-being was found to be highly significant from the 5th decile onwards, with coefficients that increase in size showing that having an income higher than the median increases well-being at a rate more than proportional.

In addition, as found in the related literature, age appears to have a U-shaped effect on well-being (Blanchflower and Oswald 2008). In our case, the turning point is found at approximately 70 years old, ${ }^{7}$ which corresponds to retirement age, at which adults might feel higher life satisfaction due to the reduced burden of responsibilities, especially with respect to reduced labor-related commitments (Gómez et al. 2016).

Sex is a variable for which previous empirical evidence has been inconclusive. In our case, results show that men experience higher levels of well-being, as in Colombia (Gómez et al. 2016) and in Mexico (Dugain and Olaberría 2015). According to Meisenberg and Woodley (2015), this is the general pattern in Latin America, in ex-communist countries and in Catholic Europe. The authors point out that this relationship might be due to the socio-cultural environment factors that impact women and men differently, such as differentiated gender roles and social expectations that could harm women's well-being.

\footnotetext{
7 The turning point for model (1) is calculated as $\frac{\partial \text { wellbeing }}{\partial \text { age }}=-0.0127+2 \times 0.00009$ age $=0 \rightarrow$ age $=\frac{0.0127}{0.00018}=70$.
} 
Table 1 Regression results

\begin{tabular}{|c|c|c|c|c|c|c|}
\hline & \multicolumn{2}{|l|}{ OLS } & \multicolumn{2}{|l|}{ Ologit } & \multicolumn{2}{|c|}{ Multilevel ologit } \\
\hline & \multicolumn{2}{|l|}{ (1) } & \multicolumn{2}{|l|}{ (2) } & \multicolumn{2}{|l|}{ (3) } \\
\hline & Coefficients & SE & Coefficients & SE & Coefficients & SE \\
\hline \multicolumn{7}{|l|}{ Contextual } \\
\hline Oil dependent & $-0.326^{*}$ & $(0.17)$ & $-0.446 * *$ & $(0.22)$ & -0.303 & $(0.22)$ \\
\hline Ln (GVA/pop) & $-0.278 * * *$ & $(0.10)$ & $-0.472 * * *$ & $(0.14)$ & -0.124 & $(0.15)$ \\
\hline Inequality & -0.252 & $(0.37)$ & -0.243 & $(0.49)$ & -0.216 & (0.63) \\
\hline Natural hazard & -0.00862 & $(0.01)$ & -0.0102 & $(0.01)$ & -0.00658 & $(0.02)$ \\
\hline Urban area & 0.000396 & $(0.00)$ & 0.000513 & $(0.00)$ & 0.00279 & $(0.00)$ \\
\hline \multicolumn{7}{|l|}{ Individual } \\
\hline Urban & -0.0438 & $(0.05)$ & -0.0921 & $(0.07)$ & -0.0646 & $(0.07)$ \\
\hline Sex & $0.102 * * *$ & $(0.03)$ & $0.126^{* * * *}$ & $(0.04)$ & $0.0916 * *$ & $(0.04)$ \\
\hline Age & $-0.0127 * * *$ & $(0.00)$ & $-0.0170^{* * *}$ & $(0.00)$ & $-0.0210^{* * *}$ & $(0.00)$ \\
\hline $\mathrm{Age}^{2}$ & $0.00009^{* *}$ & $(0.00)$ & $0.000120 * *$ & $(0.00)$ & $0.000163 * * *$ & $(0.00)$ \\
\hline Married & $0.0796^{* * *}$ & $(0.03)$ & $0.0992^{* * *}$ & $(0.04)$ & $0.153 * * *$ & $(0.03)$ \\
\hline Religion & $0.0377^{*}$ & $(0.02)$ & 0.0313 & $(0.03)$ & $0.0445^{*}$ & $(0.03)$ \\
\hline Leisure time & $0.291 * * *$ & $(0.01)$ & $0.401 * * *$ & $(0.02)$ & $0.401 * * *$ & $(0.02)$ \\
\hline Inst. trust & $0.133 * * *$ & $(0.02)$ & $0.174 * * *$ & $(0.02)$ & $0.181 * * *$ & $(0.02)$ \\
\hline Indigenous & $-0.119^{*}$ & $(0.07)$ & $-0.164 * *$ & $(0.08)$ & -0.0501 & $(0.08)$ \\
\hline Secondary & $0.124 * * *$ & $(0.02)$ & $0.142 * * *$ & $(0.03)$ & $0.169 * * *$ & $(0.03)$ \\
\hline Tertiary & 0.190 *** & $(0.04)$ & $0.235^{* * *}$ & $(0.04)$ & $0.269 * * *$ & $(0.04)$ \\
\hline Employed & $0.130 * * *$ & $(0.03)$ & $0.141^{* * *}$ & $(0.04)$ & $0.164 * * *$ & $(0.04)$ \\
\hline Socio-econ. status & $0.143 * * *$ & $(0.04)$ & $0.180^{* * *}$ & $(0.05)$ & $0.203 * * *$ & $(0.05)$ \\
\hline Health insurance & $0.0611^{* *}$ & $(0.03)$ & $0.0879 * * *$ & $(0.03)$ & $0.0692 * *$ & $(0.03)$ \\
\hline Walls & $0.210 * * *$ & $(0.03)$ & $0.273^{* * *}$ & $(0.04)$ & $0.294 * * *$ & $(0.04)$ \\
\hline Internet & $0.100 * * *$ & $(0.03)$ & $0.127 * * *$ & $(0.04)$ & $0.169 * * *$ & $(0.03)$ \\
\hline Home owner & $0.0599 * *$ & $(0.03)$ & $0.0778 * *$ & $(0.04)$ & 0.0541 & $(0.04)$ \\
\hline 2. Decile & $0.0913^{*}$ & $(0.05)$ & 0.0963 & $(0.06)$ & 0.0928 & $(0.06)$ \\
\hline 3. Decile & $0.0823 *$ & $(0.04)$ & $0.111^{*}$ & $(0.06)$ & $0.126^{* *}$ & $(0.06)$ \\
\hline 4. Decile & 0.0406 & $(0.05)$ & 0.0275 & $(0.06)$ & 0.048 & $(0.06)$ \\
\hline 5. Decile & $0.0779 *$ & $(0.05)$ & 0.0904 & $(0.06)$ & $0.115^{* *}$ & $(0.06)$ \\
\hline 6. Decile & $0.116^{* *}$ & $(0.05)$ & $0.119^{*}$ & $(0.07)$ & $0.151^{* *}$ & $(0.06)$ \\
\hline 7. Decile & $0.169^{* * *}$ & $(0.05)$ & $0.153^{* *}$ & $(0.07)$ & $0.178 * * *$ & $(0.07)$ \\
\hline 8. Decile & $0.192 * * *$ & $(0.06)$ & $0.219 * * *$ & $(0.08)$ & $0.241 * * *$ & $(0.07)$ \\
\hline 9. Decile & $0.181 * * *$ & $(0.06)$ & $0.220 * * *$ & $(0.07)$ & $0.243 * * *$ & $(0.06)$ \\
\hline 10. Decile & $0.329 * * *$ & $(0.06)$ & $0.417 * * *$ & $(0.08)$ & $0.407 * * *$ & $(0.07)$ \\
\hline Cantonal variance & & & & & $0.285^{* * *}$ & \\
\hline Observations & 21,265 & & 21,265 & & 21,265 & \\
\hline No. of cantons & 157 & & 157 & & 157 & \\
\hline $\mathrm{R}^{2}$ & 0.2027 & & 0.0664 & & & \\
\hline AIC & $75,700.53$ & & $72,686.31$ & & $71,957.57$ & \\
\hline Log likelihood & $-37,818.267$ & & $-36,302.153$ & & $-35,936.787$ & \\
\hline$\chi^{2}$ & & & 3224.16 & & 2990.62 & \\
\hline Prob $>\chi^{2}$ & 0 & & 0 & & 0 & \\
\hline
\end{tabular}

$S E$ represents standard errors

$* * * p<0.01 ; * * p<0.05, *<0.10$. Pseudo $\mathrm{R}^{2}$ for ologit. Clustered standard errors for OLS and ologit are in parentheses 
The importance of education for well-being, found also by other authors for countries in the same region (e.g., Dugain and Olaberría 2015 for Colombia; Krauss and Graham 2013 for Mexico), is confirmed in our study, supporting the policies put in place by the government.

Regarding the variables representing the dimensions of well-being in the particular case of a Latin American country, social relationships, partially proxied by leisure time and internet use, are found to have a positive and significant impact, as expected. This could also reflect the role of the Good-Living-based public policies, which have been developed with the aim that, after the satisfaction of basic needs, human well-being focuses on the enjoyment of free time, especially with family and friends (Coordinating Minister of Social Development 2014, p. 18).

The positive effect of the internet supports our hypothesis that it can be used as a platform to develop and maintain social relationships, in particular with relatives living abroad, increasing the possibility of social interactions at a distance, which is crucial for emigrants' families. According to Martínez (2007), the importance of social relationships in the region of Latin America is explained by their role in providing welfare services in the absence of strong state capacities, where unlike developed regions, access to education and health are not guaranteed. According to Beytía (2016), this differs from industrialized societies where the establishment of welfare systems has made close social ties less relevant for well-being, favoring individualistic behavior. In addition to this, the positive effect of our social relationships proxies on well-being might reflect the cultural roots of Ecuadorian society encompassed in the good living concept, where family and community are attributed intrinsic value.

Despite the low performance of institutional indicators in Ecuador, our results show that institutional trust increases well-being, as has been found for developed contexts (Hudson 2006).

We argue that our result probably reflects the effect of public policies undertaken to engage citizens in the political decision processes, potentially increasing decentralization and transparency. An example of these policies is the implementation of participatory budgeting processes at the municipal and cantonal levels. These measures, considered direct-democracy approaches, have a twofold contribution to subjective well-being by producing utility from direct participation in a political process and by producing political outcomes closer to voters' preferences (Frey and Stutzer 2000). This result is important because it suggests that improving institutions and increasing trust has great potential to contribute to well-being, in addition to being a significant driver of productivity and economic development (Acemoglu and Robinson 2008). This is further relevant for a region like Latin America, characterized by poor institutional performance and corruption.

Regarding indigenous ethnicity, results show a negative but slightly significant coefficient, in line with most empirical evidence (Neri 2016; Gómez et al. 2016, Dugain and Olaberría 2015; Shams 2016). This confirms that, in spite of the policies implemented to enhance the quality of life of indigenous people, there is still much to do given that their access to education, health and the labor market is still limited.

As is evidenced for both developed and developing countries (Lora 2008; Morcillo and de Juan Díaz 2016; Levya et al. 2016; Helliwell and Putnam 2004; Rodríguez-Pose and von Berlepsch 2014), religion is found to be a significant and positive driver of well-being in Ecuador, where the effect can be attributed to the power of social support developed in religious networks (Levya et al. 2016).

Our estimation, in line with Hurtado (2016), shows that being part of a healthcare plan, either public or private, has a positive impact on life satisfaction. As explained by Dmytraczenko and Almeida (2015), since high medical costs can lead to poverty, uncertainty about 
healthcare access is one of the mainconcerns of families in Latin American countries. Along the same line, Krauss and Graham (2013) point out that health insurance increases well-being as it is less likely that individuals are affected by medical costs, thus reducing economic insecurity and the probability of debt. Furthermore, in Ecuador, health insurance later translates into access to retirement pensions, these being lifetime-relevant. Therefore, our results might mirror the reduced psychological burden that guaranteed healthcare provides to individuals, thus allowing them to report higher well-being.

The final individual variable we considered, housing quality, is also positively associated with well-being. This might be due to two reasons: The first is that housing conditions can greatly determine the achievement of basic needs such as shelter, sleep, access to water and sanitation, and personal security (Comes et al. 2018; Krauss and Graham 2013), and the second is that housing tenure can help reduce uncertainty under harsh economic conditions (Comes et al. 2018).

At the contextual level, overall we observe low significance for all variables included in the analysis, except for oil dependence, which shows a negative impact on well-being. This supports and strengths the results of Ayelazuno (2014) and Chiasson-LeBel (2016) on the enclave nature of oil exploitation in the country, which, besides environmental damage, has generated historical class conflict and social struggle. In the Ecuadorian context, environmental degradation has special relevance because oil cantons are highly populated by indigenous communities, who, in correspondence with the concept of good living, consider nature as being just as valuable as humans and a necessary element in their holistic view of well-being (Caria and Domínguez 2016). This finding deserves major attention since oil is the leading export in Ecuador.

The low significance levels of other contextual variables suggest that once individual variables are taken into consideration, observed area differences do not affect well-being. This is in line with Ballas and Tranmer (2012), who argued that well-being might vary more across people than across places, and with the findings of Valente and Berry (2016) for Latin American countries. The latter authors indeed find that it is not the place of residence that matters for well-being in the region but, rather, familism.

We checked for the possibility that well-being does not vary at the cantonal scale but at different aggregated scale areas, i.e., by province. To explore this possibility, we analyzed the path of cantonal random effects, without finding common patterns within the same province. Secondly, we estimated the models with provincial random effects, finding that these have a higher Akaike information criterion. Third, we estimated the intra-class correlation coefficient (ICC), finding that $8 \%$ of variability is explained by between-canton differences. ${ }^{8}$ This supports the hypothesis that well-being varies not only across individuals but, partially, also across cantons. In this specific context, the lack of significance of our contextual variables might be due to their "hard" nature. Indeed, as highlighted by Haq (2009), well-being includes both "hard" and "soft" issues of human life, also referred to as objective and subjective dimensions of well-being. Malecki (2000) points out that soft variables enrich the territorial analysis beyond traditional hard measures. According to Ballas and Tranmer (2012), soft variables show that belonging to a place is associated with social and support networks, which is key to well-being. Furthermore, Malecki (2000) states that this boosts self-confidence and learning as well as the creation of business networks, which favors economic development and quality of life.

Since our contextual analysis only includes objective dimensions, in a next step, we could extend our analysis by incorporating this type of soft variable on social and relational capital, which were partially proxied at the individual level but could also be important

\footnotetext{
${ }^{8} \mathrm{We}$ followed the approach of Snijders and Bosker (2012): $I C C=\tau^{2} /\left(\tau^{2}+\pi^{2} / 3\right)=0.285 /$ $\left(0.285+3.1416^{2} / 3\right) \cong 0.08$.
} 
factors of well-being at the contextual level. However, this might not be easy to capture at such a level of spatial disaggregation.

Finally, in Table 8 in "Appendix 4", we checked if the independent variables are correlated with the regression residuals of the OLS and of the ordered logit model ${ }^{9}$ to empirically exclude endogeneity. The correlation is very close to zero, contributing to support the hypothesis of absence of endogeneity and, thus, of unbiased coefficients. Anyway, as we cannot completely exclude reverse causality issues between subjective and objective variables, we plan to do it in follow up studies.

\section{Conclusions and Policy Implications}

Our study examines the individual and contextual factors that affect individual well-being in Ecuador, focusing on aspects that characterize the socio-economic and socio-demographic structure of this country. The outcomes highlight that the individual variables commonly found to affect well-being in the literature also affect well-being in Ecuador. By means of two proxies, we show that social relationships are a positive driver of well-being. Among these, the effect of the internet has been widely debated, which makes it noteworthy that in our case it demonstrates the potential to enhance quality of life, which is an important finding within the literature on ICT use, subjective well-being, as well as on migration studies. Further analysis should be carried out to identify the elements that allow for this positive relationship, which, according to Castellacci and Tveito (2018), include personal characteristics (individual) and culture and beliefs (contextual framing).

Furthermore, we find that structural characteristics of the Latin American region such as housing quality, health security and institutional trust should be at the core of the political agenda, given their capacity to increase well-being. To this end, Ecuador has taken significant steps if we look through the lens of the National Plan for Good Living, where objectives 3, 9, 10 and 12, respectively, address these dimensions of well-being. Therefore, the policies generated should be given continuity and reinforcement in the country, and if possible, they should be replicated in other Latin American contexts.

Worth mentioning, in particular, is the critical role played by institutional trust. Institutional trust can be enhanced through the improvement of national and local institutions. Apart from the policies already implemented to increase institutional trust via increased citizen participation, according to Kyriacou et al. (2016), in developing countries this can be reached via fiscal decentralization, which can be further used to modify tax collection through increasing local accountability (Escobar-Lemmon and Ross 2014). The collection of more resources would, in turn, allow for redistributive public policies aimed at housing quality, social services, and market and social inclusion, which, as discussed, are directly linked to subjective well-being.

Despite the constitutional changes aimed at guaranteeing equal opportunities for women and ethnic minorities, this remains a public policy goal in Ecuador as well as other countries in the region (Canelas and Salazar 2014). Indeed, as shown in this study, heads of household who are women or who belong to an ethnic minority experience lower levels of well-being. This might be related to cultural heritage and to their lower access to sanitation, education, housing and labor markets relative to men, suggesting that it is important to continue to promote active integration within society and the empowerment of vulnerable sectors of the population, in compliance with objective number 1 of the National Plan for Good Living.

${ }^{9}$ Residuals of the ordered logit model are calculated following Liu and Zhang (2018). 
At the contextual level, our analysis unveils the negative role of natural resource exploitation on well-being in developing countries, where weak or inefficient institutions are not able to adequately regulate this activity, generating poor quality jobs and affecting the environment and local communities. To our knowledge, this element has received little attention in the literature on subjective well-being, despite being an important element in the economy of many developing countries and repeatedly being associated with social conflict (Chiasson-LeBel 2016).

Overall, we show that addressing socio-economic and socio-demographic characteristics of the Latin American region is essential to improve the population's quality of life. In this regard, our analysis shows that the good living framework could be used to capture some of these characteristics. Particularly through the principle of community harmony, good living allows for the acknowledgment of social relationships as a key driver of well-being, an element that has been widely recognized in the literature. Additionally, through the principle of harmony with nature, the good living concept could help to build and implement national development strategies that confer rights to nature, which could ultimately contribute to decreasing the role of extractivism and, therefore, limit its negative effects on people's well-being. Furthermore, through the principle of harmony with oneself, the good living concept focuses public policy on every aspect of life that can affect life satisfaction and its evaluation and, therefore, includes any of the dimensions analyzed here.

Despite Ecuador having been praised for implementing public policy according to the good living framework and achieving significant social and economic progress, our analysis shows that there is still room for improvement. Furthermore, it shows that structural characteristics of Latin America result in unmet basic needs, which in turn allows us to clearly differentiate the dimensions of well-being in this region relative to developed regions. Finally, results show that the influence of contextual characteristics has to be explored beyond traditional hard variables, opening possibilities for future work.

Open Access This article is licensed under a Creative Commons Attribution 4.0 International License, which permits use, sharing, adaptation, distribution and reproduction in any medium or format, as long as you give appropriate credit to the original author(s) and the source, provide a link to the Creative Commons licence, and indicate if changes were made. The images or other third party material in this article are included in the article's Creative Commons licence, unless indicated otherwise in a credit line to the material. If material is not included in the article's Creative Commons licence and your intended use is not permitted by statutory regulation or exceeds the permitted use, you will need to obtain permission directly from the copyright holder. To view a copy of this licence, visit http://creativecommons.org/licenses/by/4.0/.

\section{Appendix 1: Natural Hazards Index Methodology}

Demoraes and D'Ercole (2001) built a quantitative synthetic indicator based on the valuation of six natural hazards for 218 Ecuadorian cantons: (1) the expected magnitude (seismic), (2) the intensity (droughts), (3) the extent of the danger (landslides and floods), (4) the danger (volcanoes), (5) the recurrence (floods) and (6) the potential (tsunami, earthquakes, volcanoes). Each natural hazard was scored on a 0-2 or 0-3 scale for every canton. This information was provided by the National Institute of Meteorology and Hydrology, the Geophysical Institute of the National Polytechnic School and the Military Geographic Institute (Table 2).

The range is determined by the degree of danger represented by the potential natural disaster, as established by the institution providing the information. For instance, the 
Table 2 Score range for each of the natural hazards. Source: Demoraes and D'Ercole (2001)

\begin{tabular}{ll}
\hline Natural hazard & Score range \\
\hline Earthquake & $0-3$ \\
Tsunami & $0-2$ \\
Volcano & $0-3$ \\
Flood & $0-3$ \\
Landslide & $0-3$ \\
Drought & $0-2$ \\
Total hazard index & $0-16$ \\
\hline
\end{tabular}

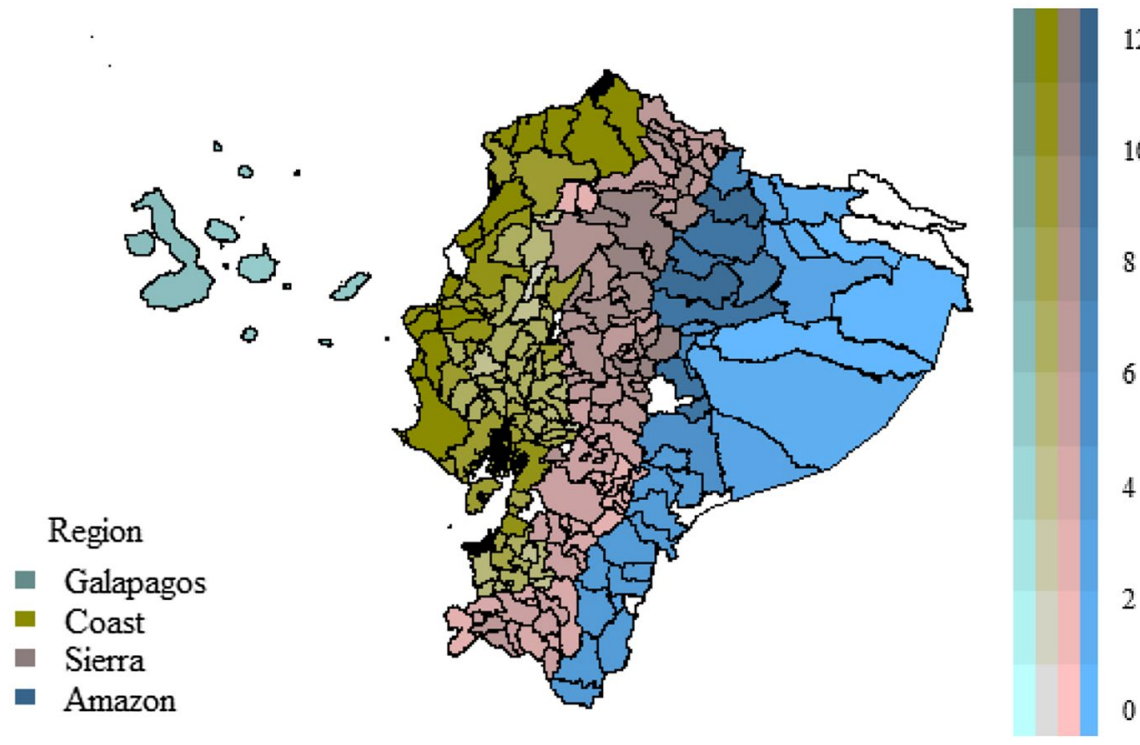

Fig. 2 Spatial distribution of the natural hazards index. Source: Authors' elaboration based on Demoraes and D'Ercole (2001)

Geophysical Institute of the National Polytechnic School points out four seismic and tsunami hazard zones. For the most dangerous zones, the score will be 3, and zero for the less dangerous. Droughts, on the other hand, have a three-category rating: strong potential (score of 2), average potential (score of 1) and weak potential (score of 0 ).

In cases where the given information shows a canton to be exposed, at least partly, to a natural hazard, all its territory is given the corresponding score. The final cantonal score is given by the addition of each natural hazard's score, and the maximum possible value for the cantonal index is 16 (Fig. 2).

\section{Appendix 2: Dimensions of Subjective Well-Being: Definition and Descriptive Statistics}

See Table 3. 
Table 3 Definition and descriptive statistics of individual variables. Source: Authors' elaboration

\begin{tabular}{|c|c|c|c|c|c|}
\hline Dimension/variable & Description & SD & Mean & Min & Max \\
\hline \multicolumn{6}{|l|}{ Individual variables } \\
\hline \multicolumn{6}{|l|}{ Area of residence } \\
\hline Urban & $1=$ if urban area of residence & 0.42 & 0.77 & 0 & 1 \\
\hline Sex & $1=$ if $\operatorname{man}$ & 0.44 & 0.73 & 0 & 1 \\
\hline Age & Age of respondent & 15 & 46 & 16 & 98 \\
\hline \multicolumn{6}{|l|}{ Civil status } \\
\hline Married & $1=$ if married respondent & 0.49 & 0.41 & 0 & 1 \\
\hline Religion & $\begin{array}{l}\text { Importance attributed to religion }(1-4=\text { the } \\
\text { highest })\end{array}$ & 0.72 & 3.53 & 1 & 4 \\
\hline \multicolumn{6}{|l|}{ Social relationships } \\
\hline Leisure time & $\begin{array}{l}\text { Personal satisfaction with available leisure } \\
\text { time }(1-10=\text { the highest })\end{array}$ & 1.91 & 7.13 & 0 & 10 \\
\hline Institutional trust & $\begin{array}{l}\text { Trust in the public defender center }(1-5=\text { the } \\
\text { highest) }\end{array}$ & 1.08 & 3.18 & 1 & 5 \\
\hline \multicolumn{6}{|l|}{ Ethnicity } \\
\hline Indigenous & $1=$ if respondent self-identifies as indigenous & 0.21 & 0.12 & 0 & 1 \\
\hline \multicolumn{6}{|l|}{ Education } \\
\hline Secondary & $1=$ if respondent reports secondary education & 0.45 & 0.28 & 0 & 1 \\
\hline Tertiary & $1=$ if respondent reports tertiary education & 0.41 & 0.21 & 0 & 1 \\
\hline \multicolumn{6}{|l|}{ Employment status } \\
\hline Employed & $1=$ if employed respondent & 0.36 & 0.84 & 0 & 1 \\
\hline Socio-economic status & $\begin{array}{l}1=\text { if respondent has a directive/managerial/ } \\
\text { scientific/intellectual job }\end{array}$ & 0.29 & 0.09 & 0 & 1 \\
\hline Health insurance & $1=$ if respondent has health insurance & 0.46 & 0.31 & 0 & 1 \\
\hline \multicolumn{6}{|l|}{ Housing quality } \\
\hline Housing safety & $1=$ if walls are in good condition & 0.50 & 0.54 & 0 & 1 \\
\hline Internet access & $1=$ if access & 0.48 & 0.37 & 0 & 1 \\
\hline Home-owner & $1=$ if home owner & 0.48 & 0.65 & 0 & 1 \\
\hline Household income & Deciles of per capita household income & 410.96 & 294.48 & 0 & 13,371 \\
\hline \multicolumn{6}{|l|}{ Contextual variables } \\
\hline Oil dependent & $1=$ if oil-dependent canton & 0.12 & 0.01 & 0 & 1 \\
\hline GVA/pop & $\begin{array}{l}\text { LN of non-oil sectors GVA (cantonal/per } \\
\text { capita) }\end{array}$ & 0.36 & 8.59 & 7.83 & 10 \\
\hline Inequality & Gini coefficient & 0.06 & 0.43 & 0.26 & 1 \\
\hline Natural hazard & Natural hazard index $(1-12=$ the highest $)$ & 2.09 & 7.36 & 0 & 12 \\
\hline Urban area & Percentage of people living in urban areas & 25.02 & 67.24 & 5.14 & 100 \\
\hline
\end{tabular}

\section{Appendix 3: Correlation Matrix}

See Table 4.

\section{Appendix 4: Robustness Check}

See Tables 5, 6, 7 . 


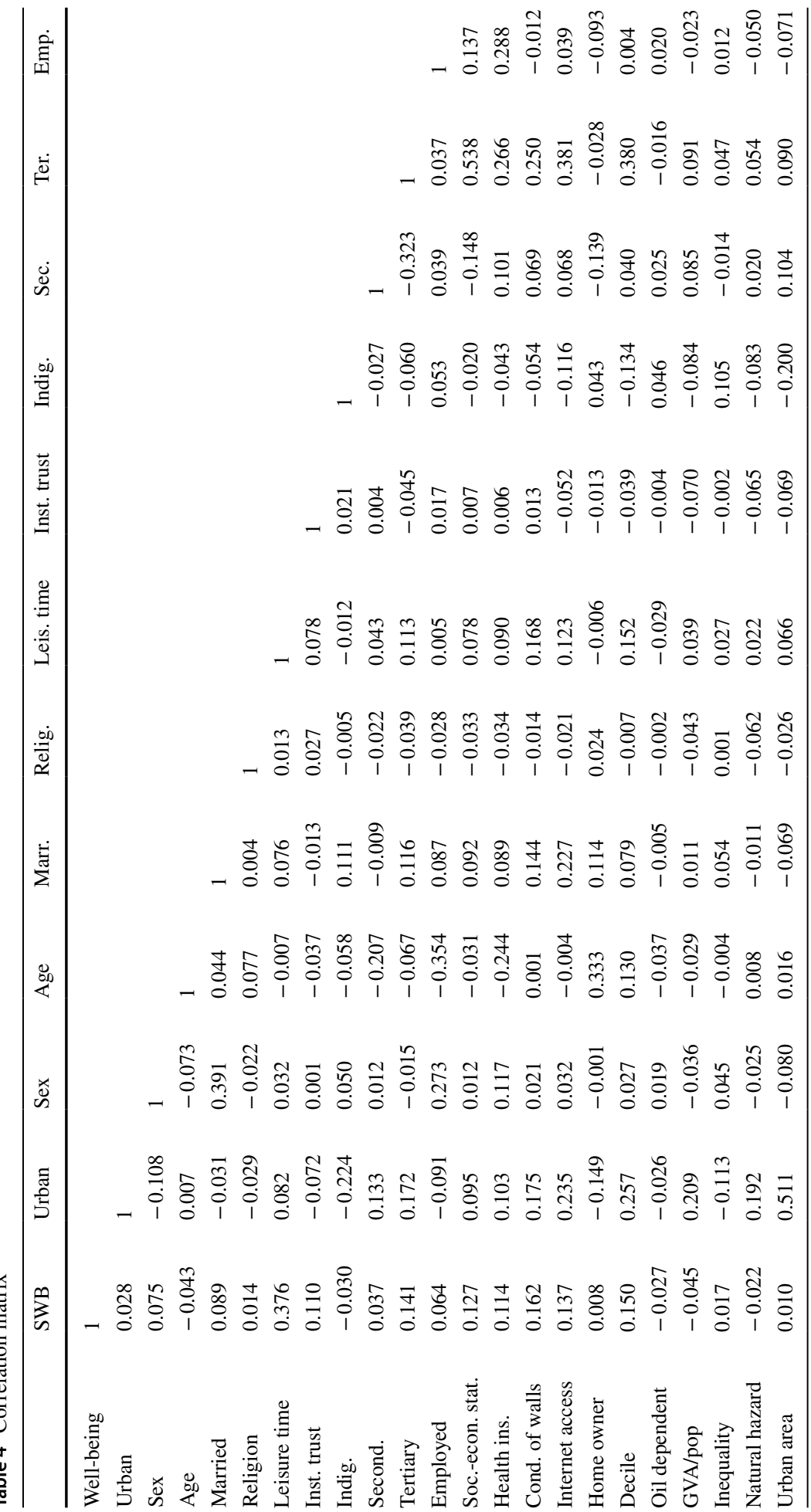




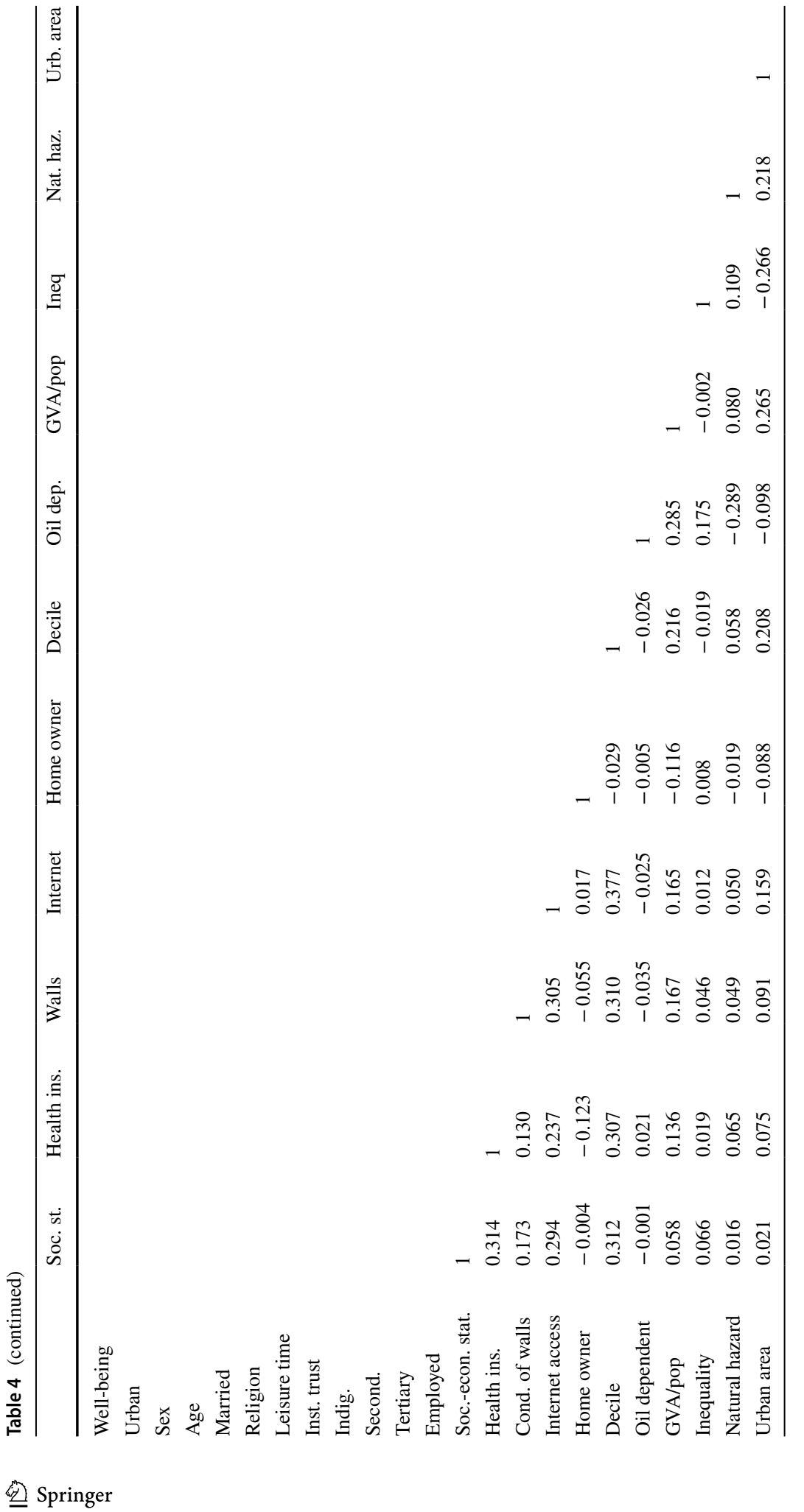


Table 5 Regression results: robustness check-at least 50 persons per canton

\begin{tabular}{|c|c|c|c|c|c|c|}
\hline & \multicolumn{2}{|l|}{ OLS } & \multicolumn{2}{|l|}{ Ologit } & \multicolumn{2}{|c|}{ Multilevel Ologit } \\
\hline & \multicolumn{2}{|l|}{ (1) } & \multicolumn{2}{|l|}{ (2) } & \multicolumn{2}{|l|}{ (3) } \\
\hline & Coefficients & SE & Coefficients & SE & Coefficients & SE \\
\hline \multicolumn{7}{|l|}{ Contextual } \\
\hline Oil dependent & $-0.325^{*}$ & $(0.17)$ & $-0.442 * *$ & $(0.21)$ & -0.311 & $(0.23)$ \\
\hline Ln (GVA/pop) & $-0.308 * * *$ & $(0.10)$ & $-0.518 * * *$ & $(0.13)$ & -0.269 & $(0.17)$ \\
\hline Inequality & -0.261 & $(0.39)$ & -0.261 & $(0.51)$ & -0.391 & $(0.66)$ \\
\hline Natural hazard & -0.007 & $(0.01)$ & -0.00779 & $(0.01)$ & -0.000835 & $(0.03)$ \\
\hline Urban area & 0.000458 & $(0.00)$ & 0.000618 & $(0.00)$ & 0.00249 & $(0.00)$ \\
\hline \multicolumn{7}{|l|}{ Individual } \\
\hline Urban & -0.0478 & $(0.06)$ & -0.0992 & $(0.07)$ & -0.0695 & $(0.07)$ \\
\hline Sex & $0.0889 * * *$ & $(0.03)$ & $0.109 * *$ & $(0.04)$ & $0.0820 * *$ & $(0.04)$ \\
\hline Age & $-0.0138 * * *$ & $(0.00)$ & $-0.0185^{* * *}$ & $(0.00)$ & $-0.0218^{* * *}$ & $(0.00)$ \\
\hline $\mathrm{Age}^{2}$ & $0.00010^{* *}$ & $(0.00)$ & $0.00014 * * *$ & $(0.00)$ & $0.00017^{* * *}$ & $(0.00)$ \\
\hline Married & $0.0868 * * *$ & $(0.03)$ & $0.109 * * *$ & $(0.04)$ & $0.154 * * *$ & $(0.04)$ \\
\hline Religion & $0.0453 * *$ & $(0.02)$ & 0.039 & $(0.03)$ & $0.0542 * *$ & $(0.03)$ \\
\hline Leisure time & $0.292 * * *$ & $(0.01)$ & $0.403 * * *$ & $(0.02)$ & $0.403 * * *$ & $(0.02)$ \\
\hline Inst. trust & $0.129 * * *$ & $(0.02)$ & $0.168^{* * *}$ & $(0.02)$ & $0.179 * * *$ & $(0.02)$ \\
\hline Indigenous & -0.105 & $(0.07)$ & $-0.144 *$ & $(0.08)$ & -0.0323 & $(0.08)$ \\
\hline Secondary & $0.124 * * *$ & $(0.02)$ & $0.146^{* * *}$ & $(0.03)$ & $0.169 * * *$ & $(0.03)$ \\
\hline Tertiary & $0.195 * * *$ & $(0.04)$ & $0.244 * * *$ & $(0.05)$ & $0.270 * * *$ & $(0.04)$ \\
\hline Employed & $0.134 * * *$ & $(0.03)$ & $0.147 * * *$ & $(0.04)$ & $0.163 * * *$ & $(0.04)$ \\
\hline Socio-econ. status & $0.134 * * *$ & $(0.04)$ & $0.165^{* * *}$ & $(0.05)$ & $0.193 * * *$ & $(0.05)$ \\
\hline Health insurance & $0.0568^{* *}$ & $(0.03)$ & $0.0837 * *$ & $(0.03)$ & $0.0650 * *$ & $(0.03)$ \\
\hline Walls & $0.206 * * *$ & $(0.03)$ & $0.270^{* * *}$ & $(0.04)$ & $0.283^{* * *}$ & $(0.04)$ \\
\hline Internet & $0.104 * * *$ & $(0.03)$ & $0.133 * * *$ & $(0.04)$ & $0.169 * * *$ & $(0.03)$ \\
\hline Home owner & $0.0576^{*}$ & $(0.03)$ & $0.0725^{*}$ & $(0.04)$ & 0.0551 & $(0.04)$ \\
\hline 2. Decile & 0.0848 & $(0.05)$ & 0.0897 & $(0.07)$ & 0.0871 & $(0.07)$ \\
\hline 3. Decile & $0.0814^{*}$ & $(0.05)$ & $0.120^{* *}$ & $(0.06)$ & $0.132 * *$ & $(0.06)$ \\
\hline 4. Decile & 0.0342 & $(0.06)$ & 0.0224 & $(0.07)$ & 0.044 & $(0.07)$ \\
\hline 5. Decile & 0.0722 & $(0.05)$ & 0.0902 & $(0.06)$ & $0.115^{* *}$ & $(0.06)$ \\
\hline 6. Decile & $0.109 *$ & $(0.06)$ & $0.118^{*}$ & $(0.07)$ & $0.145^{* *}$ & $(0.07)$ \\
\hline 7. Decile & $0.163 * * *$ & $(0.06)$ & $0.152^{* *}$ & $(0.07)$ & $0.174 * *$ & $(0.07)$ \\
\hline 8. Decile & $0.190 * * *$ & $(0.06)$ & $0.219 * * *$ & $(0.08)$ & $0.235^{* * *}$ & $(0.08)$ \\
\hline 9. Decile & $0.174 * * *$ & $(0.06)$ & $0.212 * * *$ & $(0.07)$ & $0.234 * * *$ & $(0.07)$ \\
\hline 10. Decile & $0.321 * * *$ & $(0.07)$ & $0.412 * * *$ & $(0.08)$ & $0.397 * * *$ & $(0.08)$ \\
\hline Cantonal variance & & & & & $0.274 * * *$ & \\
\hline Observations & 20,150 & & 20,150 & & 20,150 & \\
\hline N. of cantons & 116 & & 116 & & 116 & \\
\hline $\mathrm{R}^{2}$ & 0.2024 & & 0.0664 & & & \\
\hline AIC & $71,803.82$ & & $68,891.47$ & & $68,237.9$ & \\
\hline Log likelihood & $-35,869.911$ & & $-34,404.737$ & & $-34,076.949$ & \\
\hline$\chi^{2}$ & & & 3077.75 & & 2989.36 & \\
\hline Prob $>\chi^{2}$ & & & 0 & & 0 & \\
\hline
\end{tabular}

$S E$ represents standard errors

$* * * p<0.01 ; * * p<0.05 ; *<0.10$. Pseudo $\mathrm{R}^{2}$ for ologit. Clustered standard errors for OLS and ologit are in parentheses 
Table 6 Regression results: robustness check—at least 70 persons per canton

\begin{tabular}{|c|c|c|c|c|c|c|}
\hline & \multicolumn{2}{|l|}{ OLS } & \multicolumn{2}{|l|}{ Ologit } & \multicolumn{2}{|c|}{ Multilevel ologit } \\
\hline & \multicolumn{2}{|l|}{ (1) } & \multicolumn{2}{|l|}{ (2) } & \multicolumn{2}{|l|}{ (3) } \\
\hline & Coefficients & SE & Coefficients & SE & Coefficients & SE \\
\hline \multicolumn{7}{|l|}{ Contextual } \\
\hline Oil dependent & $-0.344 * *$ & $(0.17)$ & $-0.471 * *$ & $(0.21)$ & $-0.387 *$ & $(0.22)$ \\
\hline Ln (GVA/pop) & $-0.307 * * *$ & $(0.10)$ & $-0.518 * * *$ & $(0.14)$ & -0.224 & $(0.18)$ \\
\hline Inequality & -0.145 & $(0.39)$ & -0.116 & $(0.52)$ & -0.165 & $(0.64)$ \\
\hline Natural hazard & -0.00986 & $(0.01)$ & -0.0117 & $(0.01)$ & -0.0176 & $(0.02)$ \\
\hline Urban area & 0.000565 & $(0.00)$ & 0.000699 & $(0.00)$ & 0.00225 & $(0.00)$ \\
\hline \multicolumn{7}{|l|}{ Individual } \\
\hline Urban & -0.0551 & $(0.06)$ & -0.111 & $(0.08)$ & -0.0775 & $(0.07)$ \\
\hline Sex & $0.0787 * *$ & $(0.03)$ & $0.0994 * *$ & $(0.04)$ & $0.0799^{*}$ & $(0.04)$ \\
\hline Age & $-0.0148 * * *$ & $(0.00)$ & $-0.0192 * * *$ & $(0.00)$ & $-0.0228 * * *$ & $(0.00)$ \\
\hline $\mathrm{Age}^{2}$ & $0.00011^{* * *}$ & $(0.00)$ & $0.00014 * * *$ & $(0.00)$ & $0.00018^{* * *}$ & $(0.00)$ \\
\hline Married & $0.0888^{* * *}$ & $(0.03)$ & $0.110 * * *$ & $(0.04)$ & $0.153 * * *$ & $(0.04)$ \\
\hline Religion & $0.0468^{* *}$ & $(0.02)$ & 0.0426 & $(0.03)$ & $0.0540 * *$ & $(0.03)$ \\
\hline Leisure time & $0.289 * * *$ & $(0.01)$ & $0.400 * * *$ & $(0.02)$ & $0.402 * * *$ & $(0.02)$ \\
\hline Inst. trust & $0.131 * * *$ & $(0.02)$ & $0.171 * * *$ & $(0.02)$ & $0.180 * * *$ & $(0.02)$ \\
\hline Indigenous & -0.107 & $(0.08)$ & $-0.152 *$ & $(0.09)$ & -0.0642 & $(0.09)$ \\
\hline Secondary & $0.127 * * *$ & $(0.02)$ & $0.151 * * *$ & $(0.03)$ & $0.169 * * *$ & $(0.03)$ \\
\hline Tertiary & $0.190 * * *$ & $(0.04)$ & $0.240 * * *$ & $(0.05)$ & $0.268^{* * *} *$ & $(0.05)$ \\
\hline Employed & $0.131 * * *$ & $(0.03)$ & $0.144 * * *$ & $(0.04)$ & $0.163^{* * *}$ & $(0.04)$ \\
\hline Socio-econ. status & $0.120 * * *$ & $(0.04)$ & $0.148 * * *$ & $(0.05)$ & $0.177 * * *$ & $(0.05)$ \\
\hline Health insurance & $0.0695^{* * *}$ & $(0.03)$ & $0.0975 * * *$ & $(0.03)$ & $0.0698^{* *}$ & $(0.03)$ \\
\hline Walls & $0.209^{* * *}$ & $(0.03)$ & $0.273 * * *$ & $(0.04)$ & $0.285^{* * *}$ & $(0.04)$ \\
\hline Internet & $0.104 * * *$ & $(0.03)$ & $0.130 * * *$ & $(0.04)$ & $0.165^{* * *}$ & $(0.03)$ \\
\hline Home owner & $0.0591 *$ & $(0.03)$ & $0.0763 *$ & $(0.04)$ & 0.0604 & $(0.04)$ \\
\hline 2. Decile & $0.0947^{*}$ & $(0.06)$ & 0.104 & $(0.07)$ & 0.101 & $(0.07)$ \\
\hline 3. Decile & $0.0832^{*}$ & $(0.05)$ & $0.125 * *$ & $(0.06)$ & $0.138^{* *}$ & $(0.06)$ \\
\hline 4. Decile & 0.05 & $(0.06)$ & 0.0463 & $(0.07)$ & 0.0572 & $(0.07)$ \\
\hline 5. Decile & $0.0937^{*}$ & $(0.05)$ & $0.124 * *$ & $(0.06)$ & $0.143^{* *}$ & $(0.06)$ \\
\hline 6. Decile & $0.125^{* *}$ & $(0.06)$ & $0.141^{*}$ & $(0.07)$ & $0.158 * *$ & $(0.07)$ \\
\hline 7. Decile & $0.185^{* * *}$ & $(0.06)$ & $0.185^{* *}$ & $(0.07)$ & $0.197 * * *$ & $(0.07)$ \\
\hline 8. Decile & $0.213 * * *$ & $(0.06)$ & $0.253 * * *$ & $(0.08)$ & $0.256^{* * *}$ & $(0.08)$ \\
\hline 9. Decile & $0.199 * * *$ & $(0.06)$ & $0.248 * * *$ & $(0.07)$ & $0.260 * * *$ & $(0.07)$ \\
\hline 10. Decile & $0.346^{* * * *}$ & $(0.07)$ & $0.450 * * *$ & $(0.09)$ & $0.421 * * *$ & $(0.08)$ \\
\hline Cantonal variance & & & & & $0.214 * * *$ & \\
\hline Observations & 19,191 & & 19,191 & & 19,191 & \\
\hline N. of cantons & 95 & & 95 & & 95 & \\
\hline $\mathrm{R}^{2}$ & 0.2037 & & 0.0672 & & & \\
\hline AIC & $68,381.98$ & & $65,559.48$ & & $65,028.56$ & \\
\hline Log likelihood & $-34,158.989$ & & $-32,738.74$ & & $-32,472.278$ & \\
\hline$\chi^{2}$ & & & 3290.12 & & 3045.41 & \\
\hline Prob $>\chi^{2}$ & & & 0 & & 0 & \\
\hline
\end{tabular}

$S E$ represents standard errors

$* * * p<0.01 ; * * p<0.05 ; *<0.10$. Pseudo $\mathrm{R}^{2}$ for ologit. Clustered standard errors for OLS and ologit are in parentheses 


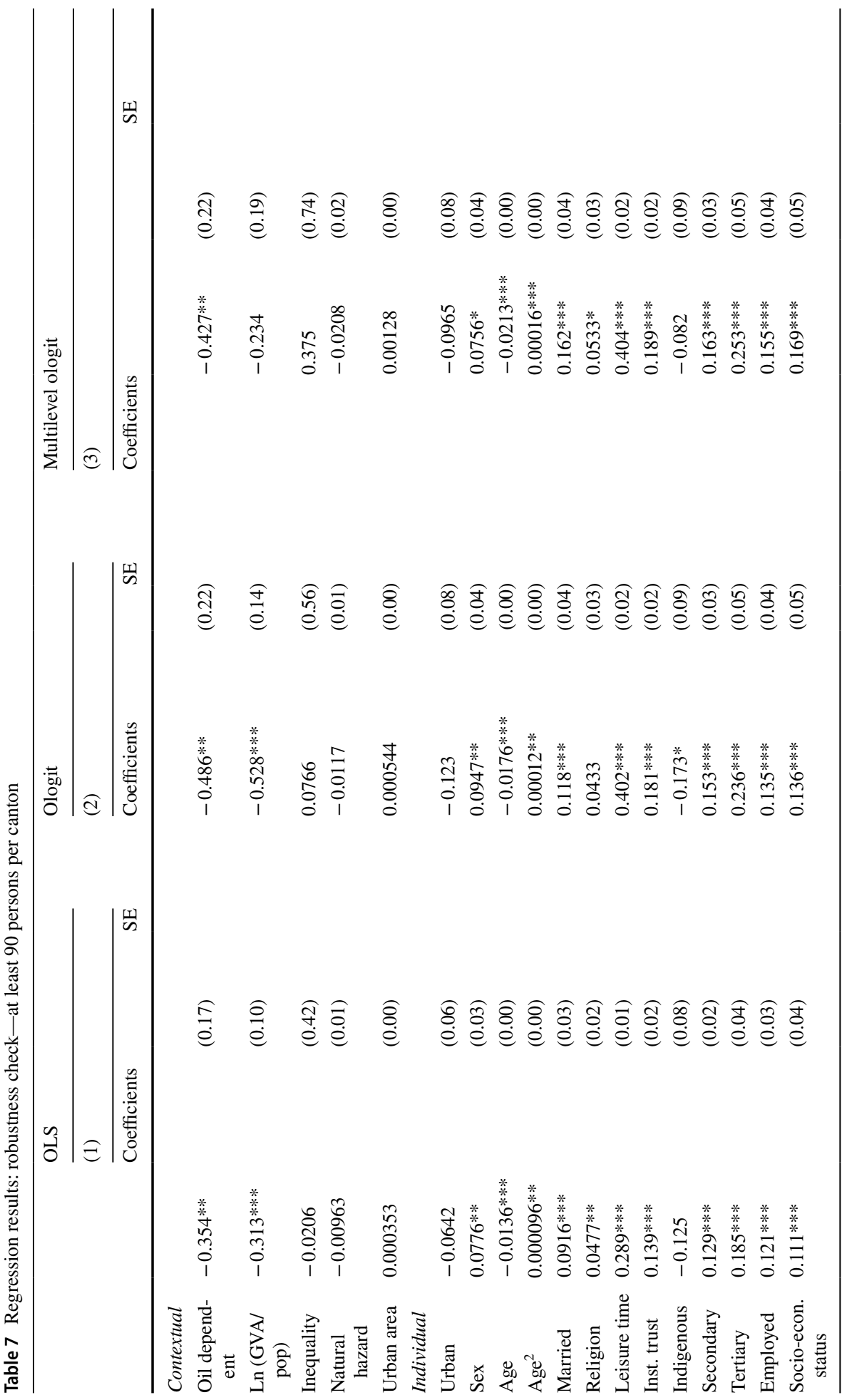




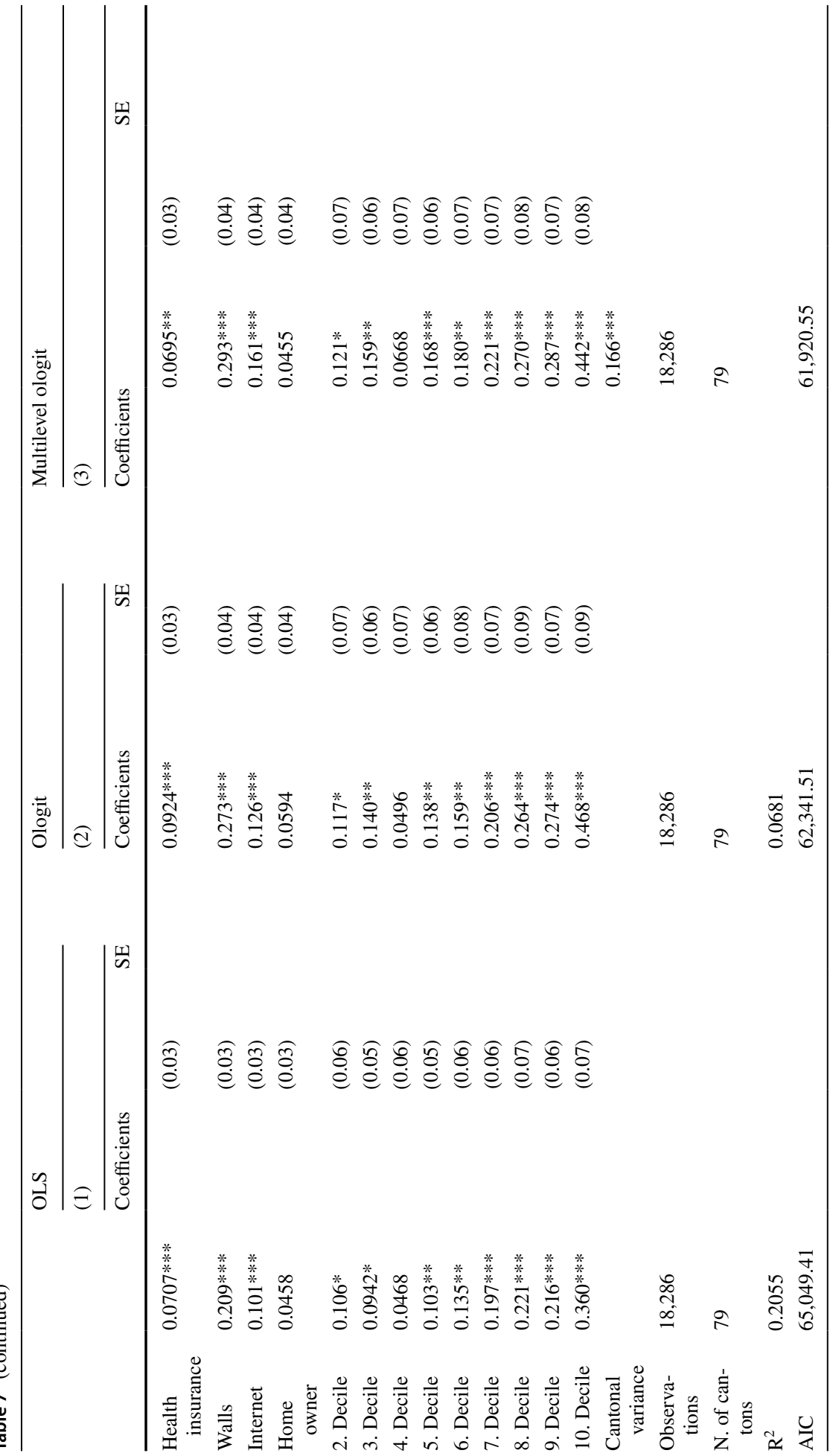




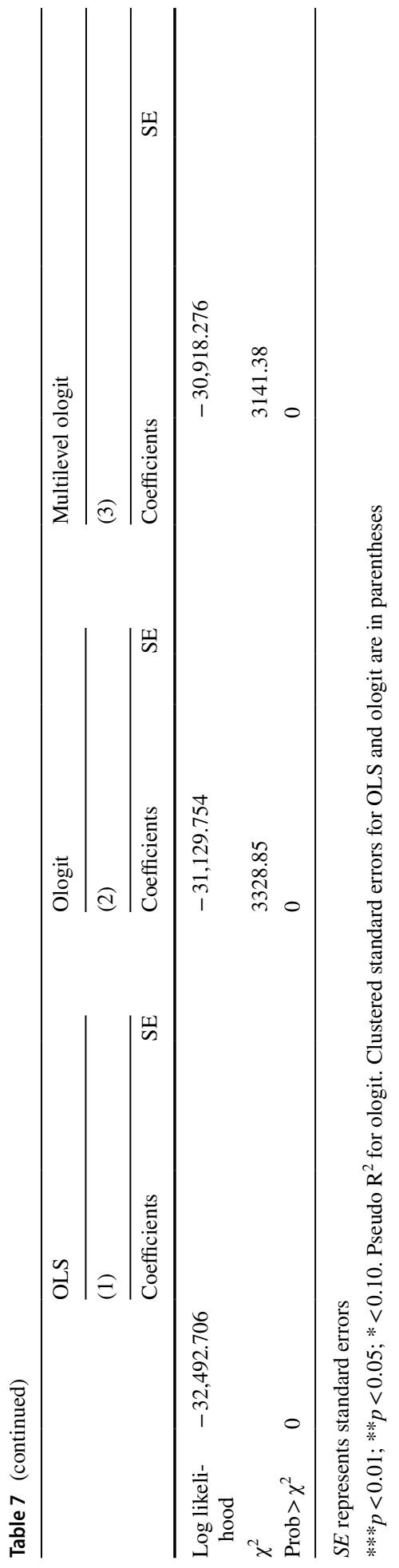


Table 8 Correlation matrix between regression residuals and independent variables

\begin{tabular}{llr}
\hline & Residuals OLS & Residuals OLOGIT \\
\hline Oil Dependent & 0.0000 & -0.0037 \\
Ln(GVA/pop) & 0.0000 & 0.0129 \\
Inequality & 0.0000 & -0.0058 \\
Natural hazard & 0.0000 & 0.0016 \\
Urban Area & 0.0000 & 0.0094 \\
Urban & 0.0000 & 0.0089 \\
Sex & 0.0000 & -0.0028 \\
Age & 0.0000 & -0.0009 \\
Married & 0.0000 & -0.0047 \\
Religion & 0.0000 & 0.0056 \\
Leisure time & 0.0000 & -0.0289 \\
Inst. trust & 0.0000 & -0.0027 \\
Indigenous & 0.0000 & -0.0009 \\
Secondary & 0.0000 & -0.0002 \\
Tertiary & 0.0000 & -0.0012 \\
Employed & 0.0000 & 0.0013 \\
Socio-Econ. status & 0.0000 & 0.0021 \\
Health insurance & 0.0000 & -0.0014 \\
Walls & 0.0000 & -0.0011 \\
Internet & 0.0000 & 0.0011 \\
Home owner & 0.0000 & -0.0033 \\
Decile & 0.0000 & -0.0002 \\
\hline & &
\end{tabular}

\section{References}

Acemoglu, D., \& Robinson, J. (2008). The role of institutions in growth and development. Washington DC: Commission on Growth and Development.

Alesina, A., Di Tella, R., \& MacCulloch, R. (2004). Inequality and happiness: Are Europeans and Americans different? Journal of Public Economics, 88, 2009-2042.

Ayelazuno, J. (2014). Oil wealth and the well-being of the subaltern classes in Sub-Saharan Africa: a critical analysis of the resource curse in Ghana. Resources Policy, 40, 66-73.

Bacigalupe, G., \& Cámara, M. (2012). Transnational families and social technologies: Reassessing immigration psychology. Journal of Ethnic and Migration Studies, 38(9), 1425-1438.

Ballas, D., \& Tranmer, M. (2012). Happy people or happy places? A multilevel modeling approach to the analysis of happiness and well-being. International Regional Science Review, 35(1), 70-102.

Bargh, J. A., \& McKenna, K. Y. (2004). The internet and social life. Annual Review of Psychology, 55, 573-590.

Benítez, J. L. (2012). Salvadoran transnational families: ICT and communication practices in the network society. Journal of Ethnic and Migration Studies, 38(9), 1439-1449.

Beytía, P. (2016). The singularity of Latin America patterns of happiness. In M. Rojas (Ed.), Handbook of happiness research in Latin America (pp. 17-30). Dordrecht: Springer.

Blanchflower, D. G., \& Oswald, A. J. (2004). Well-being over time in Britain and the USA. Journal of Public Economics, 88, 1359-1386.

Blanchflower, D. G., \& Oswald, A. J. (2008). Is well-being U-shaped over the life cycle? Social Science and Medicine, 66, 1733-1749.

BTI. (2016). Ecuador country report. Gütersloh: Bertelsmann Stiftung.

Bundesregierumg, Die. (2017). Government report on wellbeing in Germany. Berlin: Federal Press Office.

Canelas, C., \& Salazar, S. (2014). Gender and ethnic inequalities in LAC countries. IZA Journal of Labor and Development, 3, 1-18.

Caria, S., \& Domínguez, R. (2016). Ecuador's Buen vivir: A new ideology for development. Latin American Perspectives, 43, 18-33. 
Castellacci, F., \& Tveito, V. (2018). Internet use and well-being: A survey and a theoretical framework. Research Policy, 47, 308-325.

Central Bank of Ecuador. (2017). Estadísticas Económicas. Retrieved from https://www.bce.fin.ec/index .php/component/k2/item/756. Last Accessed 20 October 2017.

CEPR. (2017). Decade of reform: Ecuador's macroeconomic policies, institutional changes, and results. Retrieved from http://cepr.net/publications/reports/decade-of-reform-ecuador-s-macroeconomic-polic ies-institutional-changes-and-results. Last Accessed 20 October 2017.

Chiasson-LeBel, T. (2016). The extractive industries and society neo-extractivism in Venezuela and Ecuador: A weapon of class conflict. The Extractive Industries and Society, 3, 888-901.

Comes, M., Dubbert, M., Garschagen, M., Hagenlocher, M., Sabelfeld, R., Jin Lee, Y., et al. (2018). Vivienda ¿Qué Viene?: De Pensar la Unidad a Construir la Ciudad. Washington DC: Inter-American Development Bank.

Coordinating Minister of Social Development. (2014). Agenda Social al 2017, Quito, Ecuador.

Deeming, C., \& Jones, K. (2015). Investigating the macro determinants of self-rated health and well-being using the European Social Survey: Methodological innovations across countries and time. International Journal of Sociology, 45(4), 256-285.

Dekker, R., \& Engbersen, G. (2014). How social media transform migrant networks and facilitate migration. Global Networks, 14(4), 401-418.

Demoraes, F., \& D'ercole, R. (2001). Cartografía de riesgos y capacidades en el Ecuador. Mapa de amenazas, vulnerabilidad y capacidades en el Ecuador: Los desastres, un reto para el desarrollo. Coopi, Oxfam Internacional, SIISE. Quito, Ecuador.

Departamento Administrativo Nacional de Estadística (DANE). (2018). Encuesta Nacional del Uso del Tiempo (ENUT). Principales Resultados 2016-2017. Bogotá, Colombia.

Di Tella, R., Macculloch, R. J., \& Oswald, A. J. (2001). Preferences over inflation and unemployment: Evidence from surveys of happiness. The American Economic Review, 91, 335-341.

Dmytraczenko, T., \& Almeida, G. (2015). Toward universal health coverage and equity. In T. Dmytraczenko \& G. Almeida (Eds.), Latin America and the Caribbean: Evidence from selected countries. Washington DC: The World Bank.

Dolan, P., Layard, R., \& Metcalfe, R. (2011). Measuring subjective wellbeing for public policy: Recommendations on measures. London: Centre for Economic Performance, LSE.

Dugain, V., \& Olaberría, E. (2015). What makes Mexicans happy? OECD Economics Department Working Papers, no 1196, pp. 0-32.

Easterlin, R. (1974). Does economic growth improve the human lot? Some empirical evidence. In P. David \& M. Reder (Eds.), Nations and households in economic growth: Essays in honor of Moses Abramowitz (pp. 89-125). New York: Academic Press.

Escobar-Lemmon, M., \& Ross, A. D. (2014). Does decentralization improve perceptions of accountability? Attitudinal evidence from Colombia. American Journal of Political Science, 58, 175-188.

Espinosa, A. M., Horna, L., Mendieta Muñoz, R., \& Pontarollo, N. (2019). The statistical properties of the networks of emigrants: The Ecuadorian case. International Migration, 57(4), 40-57.

Ferrer-i-Carbonell, A., \& Frijters, P. (2004). How important is methodology for the estimates of the determinants of happiness? The Economic Journal, 114, 641-659.

Fleche, S., Smith, C., \& Sorsa, P. (2011). Exploring determinants of subjective wellbeing in OECD countries: Evidence from the world value survey. OECD Economics Department Working Papers, Paris.

Freedom House. (2017). Freedom in the World 2017. Retrieved from https://freedomhouse.org/report/freed om-world/freedom-world-2017. Last accessed 20 October 2017.

Frey, B. S., \& Stutzer, A. (2000). Happiness, economy and institutions. The Economic Journal, 110, $918-938$.

Gadom, D. G., Mboutchouang, A. K., Nadege Djossou, G., Quentin, K. G., \& Araar, A. (2017). The impact of oil exploitation on wellbeing in Chad. Partnership for Economic Policy Working Paper (2017-06).

Gallup International. (2017). End of year 2016. Global report on religion. WIN/Gallup International.

Ganju, K. K., Pavlou, P. A., \& Banker, R. D. (2016). Does information and communication technology lead to the well-being of nations? A country-level empirical investigation. MIS Quarterly, 40, 417-430.

Garschagen, M., Hagenlocher, M., Comes, M., Dubbert, M., Sabelfeld, R., Lee, Y. J., Grunewald, L., Lanzendörfer, M., Mucke, P., Neuschäfer, O., Pott, S., Post, J., Schramm, S. Schumann-Bölsche, D., Vandemeulebroecke, B., Welle, T., \& Birkmann, J.(2016). World risk report 2016. Berlin: Bündnis Entwicklung Hilft and UNU-EHS.

Gómez, C., Suárez, G., Garzón, J. E., \& Gómez, J. (2016). El Ser y el Tener de los Habitantes de la Ciudad de Medellín Como Determinantes de la Satisfacción con la Vida. Centro de Investigaciones Económicas Y Financieras. Universidad EAFIT, 16, 432.

Graham, C., \& Felton, A. (2006). Inequality and happiness: Insights from Latin America. Journal of Economic Inequality, 4(1), 107-122. 
Graham, C., \& Nikolova, M. (2015). Bentham or Aristotle in the development process? An empirical investigation of capabilities and subjective well-being. World Development, 68, 163-179.

Haq, R. (2009). Measuring human wellbeing in Pakistan: Objective versus subjective indicators. European Journal of Social Sciences, 9, 516-529.

Helliwell, J. (2002). How's life? Combining individual and national variables to explain subjective wellbeing. NBER Working Papers, No. 9065.

Helliwell, J., Layard, R., \& Sachs, J. (2017). World happiness report 2017. New York: Sustainable Development Solutions Network.

Helliwell, J., \& Putnam, R. (2004). The social context of well-being. Philosophical Transactions of the Royal Society London B, 359, 1435-1446.

Hofstede, G. (1984). Culture's consequences: International differences in work-related values (Vol. 5). Thousand Oaks: Sage Publications.

Hox, J. (1995). Applied multilevel analysis. Amsterdam: TT-Publikaties.

Hudson, J. (2006). Institutional trust and subjective well-being across the EU. KYKLOS, 59, 43-62.

Hudson, P., Botzen, W. J. W., Poussin, J., \& Aerts, J. C. J. H. (2019). Impacts of flooding and flood preparedness on subjective well-being: A monetisation of the tangible and intangible impacts. Journal of Happiness Studies, 20(2), 665-682.

Hurtado, D. A. (2016). Socioeconomic disparities in subjective well-being in Colombia. In M. Rojas (Ed.), Handbook of happiness research in Latin America (pp. 343-356). Dordrecht: Springer.

IMF. (2015). IMF Country Report. Retrieved from https://www.imf.org/external/pubs/ft/scr/2015/cr152 89.pdf. Last Accessed 20 October 2017.

INEC. (2012). Primeras Estadísticas Oficiales sobre Filiación Religiosa en el Ecuador. Quito.

INEC. (2015). Encuesta Nacional de Empleo, Desempleo y Subempleo Urbano (ENEMDU).

INEC. (2018). Encuesta Nacional del Uso del Tiempo 2017. San José: Resultados generales.

Kahneman, D., \& Deaton, A. (2010). High income improves evaluation of life but not emotional well-being. PNAS, 107, 16489-16493.

Kavetsos, G., \& Koutroumpis, P. (2011). Technological affluence and subjective well-being. Journal of Economic Psychology, 32(5), 742-753.

Knight, J., Song, L., \& Gunatilaka, R. (2009). Subjective well-being and its determinants in rural China. China Economic Review, 20, 635-649.

Krauss, A., \& Graham, C. (2013). Subjective wellbeing in Colombia: Some insights on vulnerability, job security, and relative incomes. International Journal of Happiness and Development, 1, 233-260.

Kuroki, M. (2011). Does social trust increase individual happiness in Japan? The Japanese Economic Review, 62, 444-459.

Kyriacou, A. P., Muinelo-Gallo, L., \& Roca-Sagalés, O. (2016). Regional inequalities, fiscal decentralization and government quality. Regional Studies, 51, 945-957.

Leifsen, E., \& Tymczuk, A. (2012). Care at a distance: Ukrainian and Ecuadorian transnational parenthood from Spain. Journal of Ethnic and Migration Studies, 38(2), 219-236.

Leyva, G., Bustos, A., \& Romo, A. M. (2016). Life satisfaction and happiness in Mexico: Correlates and redundancies. In M. Rojas (Ed.), Handbook of happiness research in Latin America (pp. 579-611). Dordrecht: Springer.

Liu, D., \& Zhang, H. (2018). Residuals and diagnostics for ordinal regression models: A surrogate approach. Journal of the American Statistical Association, 113(522), 845-854.

Lora, E. (2008). Beyond facts. Understanding Quality of Life (Development in the Americas). Washington DC: Inter-American Development Bank.

Malecki, E. J. (2000). Soft variables in regional science. Review of Regional Studies, 30(1), 61-69.

Martínez, J. (2007). Regímenes de Bienestar en América Latina. Madrid: Fundación Carolina.

McNeish, D., Stapleton, L., \& Silverman, R. S. (2017). On the unnecessary ubiquity of hierarchical linear modeling. Psychological Methods, 22, 114-140.

Meisenberg, G., \& Woodley, M. A. (2015). Gender differences in subjective well-being and their relationships with gender equality. Journal of Happiness Studies, 16(6), 1539-1555.

Mendieta Muñoz, R., \& Pontarollo, N. (2016). Cantonal convergence in Ecuador: A spatial econometric perspective. Journal of Applied Economic Sciences, 39(11), 107-126.

Mendoza-Botelho, M. (2013). Social capital and institutional trust: Evidence from Bolivia's popular participation decentralisation reforms. The Journal of Development Studies, 49(9), 1219-1237.

Modrego, F., \& Berdegué, J. A. (2015). A large-scale mapping of territorial development dynamics in Latin America. World Development, 73, 11-31.

Massala R., \& Monni, S. (2019). The social inclusion of indigenous peoples in Ecuador before and during the Revolución Ciudadana. Development (forthcoming). 
Morcillo, F. M., \& de Juan Díaz, R. (2016). Happiness and social capital: Evidence from Latin American countries. In M. Rojas (Ed.), Handbook of happiness research in Latin America (pp. 143161). Dordrecht: Springer.

Morris, S. D., \& Klesner, J. L. (2010). Corruption and trust: Theoretical considerations and evidence From Mexico. Comparative Political Studies, 43(10), 1258-1285.

Moulton, B. R. (1986). Random group effects and the precision of regression estimates. Journal of Econometrics, 32, 385-397.

Nedelcu, M. (2012). Migrants' new transnational habitus: Rethinking migration through a cosmopolitan lens in the digital age. Journal of Ethnic and Migration Studies, 38(9), 1339-1356.

Neri, M. (2016). A perceived human development index. In M. Rojas (Ed.), Handbook of happiness research in Latin America (pp. 557-577). Dordrecht: Springer.

OECD. (2009). Society at a glance 2009, OECD social indicators. Paris: OECD Publishing.

OECD. (2013). OECD guidelines on measuring subjective well-being. Paris: OECD Publishing.

Orellana Bravo, M. R., Raileanu Szeles, M., \& Argudo Barrera, D. M. (2016). A multilevel analysis of the returns to education in Ecuador. The multifaceted impact of human capital. Scientific Annals of Economics and Business, 63, 1-19.

Pénard, T., Poussing, N., \& Suire, R. (2013). Does the internet make people happier? The Journal of Socio-Economics, 46, 105-116.

Ramirez, R. (2009). La Felicidad Como Medida del Buen Vivir en Ecuador. Quito: Plataforma Buen Vivir.

Rice, N., \& Jones, A. (1997). Multilevel models and health economics. Health Economics, 6, 561-575.

Rodríguez-Pose, A., \& von Berlepsch, V. (2014). Social capital and individual happiness in Europe. Journal of Happiness Studies, 15, 357-386.

Rojas, M. (2018). Happiness in Latin America has social foundations. In J. F. Helliwell, R. Layard, \& J. D. Sachs (Eds.), World happiness report. New York: United Nations.

Rozer, J., \& Kraaykamp, G. (2013). Income inequality and subjective well-being: A cross-national study on the conditional effects of individual and national characteristics. Social Indicators Research, 113, 1009-1023.

SENPLADES. (2009). Plan Nacional del Buen Vivir 2009-2013, Quito.

SENPLADES. (2013a). Atlas de las Desigualdades Socio-Económicas del Ecuador. Quito.

SENPLADES. (2013b). Plan Nacional del Buen Vivir 2013-2017. Quito.

SENPLADES, \& SETEP. (2014). Estrategia Nacional para la Igualdad y la Erradicación de la Pobreza. Quito.

Shams, K. (2016). Developments in the measurement of subjective well-being and poverty: An economic perspective. Journal of Happiness Studies, 17, 2213-2236.

Snijders, T. A. B., \& Bosker, R. (2012). Multilevel analysis. Thousand Oaks, CA: Sage.

Stiglitz, J. (2014). The price of inequality: How today's divided society endangers our future. In Sustainable humanity sustainable nature our responsibility. Pontifical Academy of Sciences, Extra Series 41, Vatican City (Vol. 2014, pp. 1-21).

Stiglitz, J., Sen, A., \& Fitoussi, J.-P. (2009). Report by the Commission on the Measurement of Economic Performance and Social Progress. (French Commission on the Measurement of economic Performance and social Progress).

Tavernier, J. L., Cuneo, P., \& Plateau, C. (2015). Measurement of quality of life and well-being in France: The drivers of subjective well-being. Review of Income and Wealth, 61, 25-33.

Transparency International. (2015). Corruption Perceptions Index. Retrieved from https://www.transparen cy.org/. Last Accessed 20 October 2017.

Valente, R. R., \& Berry, B. J. L. (2016). Dissatisfaction with city life? Latin America revisited. Cities, 50, 62-67.

Van Praag, B., \& Ferrer-i-Carbonell, A. (2008). Happiness quantified. A satisfaction calculus approach. Oxford: Oxford University Press.

World Bank. (2015). Ecuador: Social Indicators. Retrieved from https://datos.bancomundial.org/. Last Accessed 20 October 2017.

World Values Survey. (2015). World values survey. http://www.worldvaluessurvey.org/wvs.jsp.

Zagorski, K., Evans, M. D. R., Kelley, J., \& Piotrowska, K. (2014). Does national income inequality affect individuals' quality of life in Europe? Inequality, happiness, finances, and health. Social Indicators Research, 117, 1089-1110.

Publisher's Note Springer Nature remains neutral with regard to jurisdictional claims in published maps and institutional affiliations. 